\title{
Anthropomorphised warlike beings with horned helmets: Bronze Age Scandinavia, Sardinia, and Iberia compared
}

https://doi.org/10.1515/pz-2021-2012

Zusammenfassung: Das Auftreten und die Darstellung gehörnter Helme im bronzezeitlichen Nordeuropa regt bis in die Gegenwart Diskussionen darüber an, was davon lokal und was fremd ist. Abbildungen gehörnter Helme finden sich in ganz Europa und dem angrenzenden Mittelmeerraum in einem Zeitraum von 1000-750 v. Chr. Diese Studie beschäftigt sich detailliert mit einer vergleichenden Analyse der Darstellung gehörnter Helme, ausgehend von der Frage, wie ähnlich sich die verwendeten Materialien, das Medium selbst und die kulturellen Kontexte sind. Sardinien, das südwestliche Spanien und Portugal (Iberische Halbinsel) sowie Südskandinavien sind innerhalb dieser Untersuchung von besonderem Interesse, da hier anthropomorphe kriegerähnliche Kreaturen mit gehörnten Helmen in der materiellen und ikonographischen Kultur auftreten. Die Analysen enthüllen Ähnlichkeiten und Unterschiede zwischen den drei Zonen in der Darstellung dieser gehörnten Figuren, der Art und Weise, wie sie dargestellt werden und der Eingliederung dieses Phänomens in Rituale und Alltägliches um 1000-750 v. Chr.

Obwohl auch lokale Eigenheiten deutlich herausgearbeitet werden können, ist eine Verbindung dieser drei Regionen nicht zu leugnen. Übergreifend betrachtet können die Hörner als Zeichen der Potenz des Helmträgers interpretiert werden. Sie gelten als Inbegriff eines Kriegers und visualisieren eine begrenzte Gruppe von kriegerischen Wesen. Ihre Bedeutung scheint eng verbunden

*Corresponding author: Helle Vandkilde, Aarhus University, School of Culture and Society, Moesgaard Allé 22, DK-8270 Højbjerg.

E-Mail: farkhv@cas.au.dk

Valentina Matta, Aarhus University, School of Culture and Society, Moesgaard Allé 22, DK-8270 Højbjerg. E-Mail:

valentina.matta@cas.au.dk

Laura Ahlqvist, Aarhus University, School of Culture and Society, Moesgaard Allé 22, DK-8270 Højbjerg. E-Mail:

laura.ahlqvist@cas.au.dk

Heide W. Nørgaard, Moesgaard Museum, Moesgaard Allé 15, DK-8270 Højbjerg. E-Mail: hn@moesgaardmuseum.dk mit Riten, Orten und Überzeugungen und zeugt auch von einer engen Verbindung zu politischen Prozessen.

Wir schlussfolgern, dass die ins Auge fallenden Abbildungen von gehörnten Insignien tragenden Männern eine Kennzeichnung des „Besonderen“ sind. Sie könnten einerseits als ein Ausdruck oder die Verbildlichung für die lokale Kontrolle von Metallen zu sehen sein und sollten andererseits als ein Zeichen für die Übertragung neuartiger Überzeugungen und Kulte, die eine verkörperte Gigantisierung beinhalten, verstanden werden. Darstellungen gehörnter Figuren haben eine komplexe Geschichte im spätbronzezeitlichen Mittelmeer und entspringen der Levante. Der skandinavische Raum nimmt diese Elemente und teils auch Ideologien vermutlich um $1000 \mathrm{v}$ Chr. auf, zusammenfallend mit der metallgeführten phönizischen Expansion und Konsolidierung nach Westen. Dies führt zu einer Etablierung einer MittelmeerAtlantik-Seeroute, während die im 2. Jahrtausend vorherrschende transalpine Handelsroute immer inaktiver wird und schließlich verebbt. Bei der vergleichenden Auswertung von bildlichen Darstellungen, zum Beispiel der Felskunst und plastischen Darstellungen gehörnter Figuren, zeigte sich, dass diese teils an lokale Riten und Gebräuche angepasst wurden, auf andere jedoch sparsam oder gar keinen Einfluss hatten.

Schlüsselworte: Späte Bronzezeit, lokal vs. global, Krieger-Kult, Gigantisierung, Metallhandel und westliche SeeRoute.

Abstract: Horned-helmet imagery continues to raise questions about what is local and what is global in Bronze Age Europe. How similar is the imagery found on Sardinia, in southwestern Iberia and southern Scandinavia in material appearance, medium of representation, and sociocultural setting? Does it occur at the same point in time? Does it spring from or transmit a shared idea? Analysis reveals intriguing patterns of similarity and difference between the three zones of horned-helmet imagery 1000-750 BC. The results point to actors and processes at the local level 
while also pinpointing interconnections. Across all three contexts, horns signify the potency of the helmet wearer, the quintessential warrior. Horns visualise a defined group of bellicose beings whose significance stems from commemorative and mortuary rites, sites, and beliefs - in conjunction with political processes. We suggest that the eye-catching imagery of very particular males wearing horned insignia relates on the one hand to local control of metals and on the other to the transfer of novel beliefs and cults involving embodied gigantisation. It is characteristic that the horned figure is adapted into some settings, but only sparingly or not at all in others. This imagery has a complex history, with Levantine roots in the LBA Mediterranean. The Scandinavian addendum to the network coincides with the metal-led Phoenician expansion and consolidation in the west from c. 1000 BC. A Mediterranean-Atlantic sea route is suggested, independent of the otherwise flourishing transalpine trading route.

Keywords: Final Bronze Age, local-global, imagery and narratives, warrior-cult, gigantisation, sanctuary, cult, political power, metal-control and western sea route

Riassunto: L'interpretazione iconografica di individui che indossano elmi cornuti continua a sollevare domande su cosa sia locale e globale nell'ambito figurativo dell'Europa dell'Età del Bronzo. Il presente contributo ha lo scopo di individuare gli elementi in comune e quelli di divergenza tra tre zone (Sardegna, Penisola Ibérica e Scandinavia) nel periodo 1000-750 a.C. Quali sono le somiglianze tra le rappresentazioni di età nuragica, quelle della Penisola Ibérica e il sud della Scandinavia per quanto riguarda il repertorio iconografico, il materiale utilizzato e il contesto socio-culturale? Queste somiglianze hanno origine in maniera indipendente, oppure sono frutto della trasmissione di idee tra le diverse regioni? Nelle tre regioni a confronto, la figura dell'elmo cornuto si adatta ad alcuni contesti, mentre risulta sporadica o del tutto assente in altri. L'iconografia presenta una storia complessa che ha origini in area levantina e si diffonde nel resto del Mediterraneo ed in Europa almeno dal Bronze Recente. Laggiunta della Scandinavia al network coincide con l'apertura di una nuova rotta atlantica e con la consolidazione dell'espansione fenicia motivata dalla ricerca di nuove risorse metallifere nel Mediterraneo occidentale (circa 1000 a.C.). I risultati dell'indagine supportano l'ipotesi che queste rappresentazioni scaturiscano sia da processi di tipo locale sia da elementi di interconnessione tra le regioni analizzate. In tutte e tre le aree, l'elmo cornuto viene utilizzato per esprimere la potenza dell'individuo che lo indossa, la quintessenza del guerriero. Le corna diventano elemento per identificare un preciso gruppo di individui i cui simboli, spesso legati all'ambito bellico, vengono esibiti in rituali commemorativi di frequente legati all'ambito funerario. I valori associati alla parure bellica vengono celebrati all'interno di contesti nei quali processi di tipo sociale e politico si mescolano con l'ambito rituale del sacro. Tra i gli elementi comuni, la rappresentazione dello sguardo e elementi decorativi somiglianti di alcuni individui con elmi cornuti potrebbe associarsi a due fenomeni: da una parte la diffusione di simboli attarverso il commercio del metallo tra le tre zone e dall'altra la diffusione di credenze e culti associati al fenomeno della gigantizzazione dell'individuo.

Parole chiave: Bronzo Finale, locale-globale, immagini e narrativa, culto del guerriero, gigantizzazione, santuario, culto, potere politico, controllo del metallo, rotte marittime occidentali

\section{Introduction to the horned-helmet theme}

The only extant horned metal helmets are those from Viks $\emptyset$, Denmark ${ }^{1}$. This pair of twin helmets communicates to the onlooker an extraordinary agency, suggesting that their wearers wielded power, whether perceived as god, human, or something in between. The Viks $\varnothing$ helmets are not entirely unique, however. Similar imagery is portrayed, in differing media and on differing scales, both within and outside Denmark. The present contribution concerns representations of horned-helmet creatures in the Late Bronze Age and the earliest Iron Age $^{2}$. This specific figure is usually associated with weapons and gear calling to mind the concept of the warrior's beauty ${ }^{3}$, but the meaning of the figure in several respects transcends this. The horned-helmet figure is not a standard representation of later Bronze Age warriorhood: other helmet types and human-like figures also occur. Rather, it conveys specific meanings, both local and overarching, that are challenging to unveil. The horned figure will be termed 'warrior' in what follows, even if this term is not entirely comprehensive, and our use of the term 'imagery/image'

1 See Norling-Christensen 1943; 1946a; 1946b; Hencken 1971; Thrane 1975, 62-66.

2 Different terminologies are in use for the same chronological interval. Early Iron Age (EIA) in the Mediterranean corresponds to Late Bronze Age (LBA) in central and northern Europe.

3 Treherne 1995. 


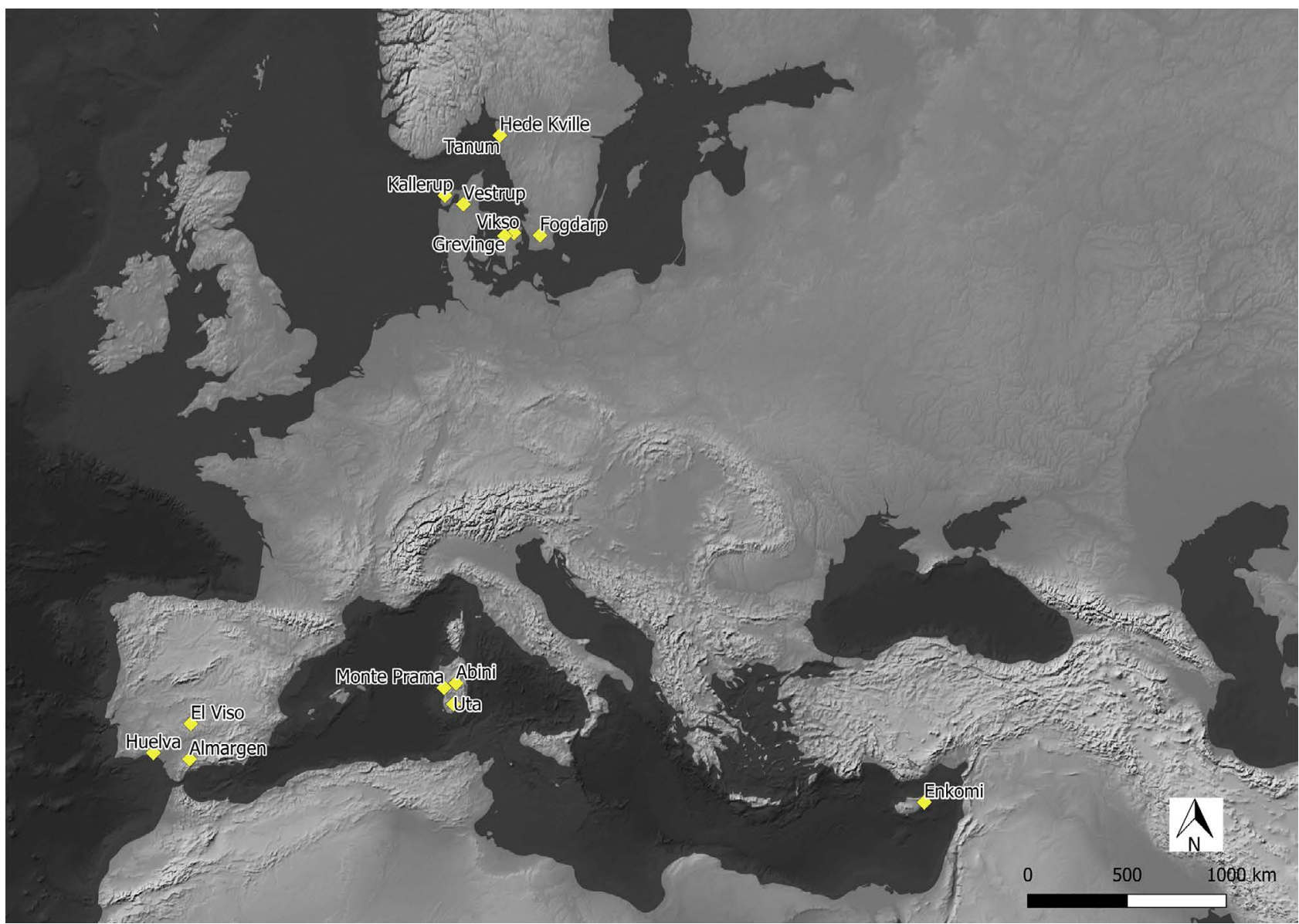

Fig. 1: The three geographical zones with horned-helmet representations analysed in this article: Sardinia, southwest Iberia, and southern Scandinavia, with selected key sites. The distinctly western European focus hints at connections between the western Mediterranean Sea, the Atlantic sea façade, and the Scandinavian part of the North Sea and inner waters. () V. Matta.

recognises a set of underlying ideas or situations. The geographical range of the figure reveals three zones - a southern zone in Sardinia and adjoining parts of Corsica, a middle zone in southwestern Iberia, and a northern zone in southern Scandinavia - thus highlighting three seas and potential movements over vast distances (Fig. 1). The horned warrior occurs in these three settings, but sparingly or not at all in the rest of Europe ${ }^{4}$ - except in the Near East and the east Mediterranean region, which boast a deep history of horned-helmet figures connected with divine rulership and with warfare at the time when the longstanding Bronze Age civilisation there was in rapid transition c. $1200 \mathrm{BC}$.

Three possible explanatory scenarios for the horns can be outlined: firstly, that they arose from autonomous local processes; secondly, that they were products of multidirectional culture flows in a phase of globalisa- tion $^{5}$; and thirdly, that they were the product of directional movements of goods and ideas as they were strategically appropriated by local culture and society. In the first two scenarios, the similarities between the figures are random and not directly connected, while in the third scenario, the interconnections are concrete and the result of planned movements.

If the figures are interlinked, their distinctly zone-specific occurrence may reveal relations between the Nordic Bronze Age, the Atlantic Bronze Age, and the West Mediterranean Bronze Age. This is not unlikely, as demonstrated by similar-style bronze objects present in parts of or across this huge area, with threads leading far into the east Mediterranean Sea: for example, Herzsprung-type round shields, Carp's Tongue swords, swords of Monte Sa'Idda type, mirrors, Huelva-type elbow brooches, Atlantic type cauldrons, roasting spits and flesh hooks, British-type 
socketed spearheads, and spearheads of Vénat type ${ }^{6}$. Furthermore, it has been suggested that copper from various ore provenances moved along these pathways ${ }^{7}$. Tin was a crucial travelling commodity, likely provided especially by Cornwall, an important hub from early on ${ }^{8}$.

Recent decades of research have strengthened the view that the Bronze Age was reliant on coveted metals traded in vast amounts and often long distance, hence connecting metal-rich tracts with regions poor in metals. Regular trade was made necessary by the unequal natural distribution of copper and, in particular, tin. The metals of gold, silver, and lead followed suit. Recent research has conceptualised this process, simultaneously local and global, as bronzization ${ }^{9}$. Other desirable commodities are known to have travelled far and wide, notably Baltic amber and Egyptian-Mesopotamian blue glass while exotic spices and cuisine culture have recently been added to the suite hence matching recent clear evidence of shared weighing technology from the east Mediterranean along the Atlantic façade as far as Britain and Scandinavia $^{10}$. Such commodities were perhaps traded in return for or transported along with the metals. A shifting panoply of finished objects also travelled, notably weaponry and ceremonial drinking gear ${ }^{11}$. Local production and the serial spread of material simulacra constitute a further layer of cultural exchange, if one that is generally less well understood. Several of the war-effective flanged-hilted swords of the later Bronze Age seem to be locally made, albeit they suggest an international style among a professional set of warriors ${ }^{12}$. Similarly, large round shields in bronze appear in several variants ${ }^{13}$, and protective armour appears across Europe $^{14}$. In other cases, objects present themselves as similar to an original in a manner that reveals leeway for local tradition and taste. Local Scandinavian emulations of Hajdúsámson-style metal-hilted swords and daggers were fashionable at an early stage of the Middle Bronze $\mathrm{Age}^{15}$. Beliefs tied to the sun-bird-ship motif likewise trav-

6 Harrison 2004, figs 7,7; 7,10-11; 7,20; 7,23; 8,2-4; Kristiansen 1998, 77 figs 72-75; Cleary/Gibson 2019, fig. 4,19.

7 Ling et al. 2012; Ling et al. 2014; Ling et al. 2019; Melheim et al. 2018.

8 Berger et al. 2019; Vandkilde 2017, 142-175.

9 Vandkilde 2016.

10 Scott et al. 2021; Varberg et al. 2016. Ialongo et al. 2021; cf. Vandkilde 2021.

11 For example Hansen 1995; Kristiansen 1998, 161-185; Thrane 1975. 12 See Harding 2007; Jung et al. 2011; Kristiansen/Suchowska-Ducke 2015; Molloy 2010, 2018; Stockhammer 2004.

13 Uckelmann 2012.

14 Mödlinger 2015; 2017.

15 Sørensen 2012; Vandkilde 2014. elled widely across Urnfield Europe, perhaps rooted in the Mediterranean post-Bronze Age world ${ }^{16}$. The overall picture suggests that raw materials, ready-mades, and religious ideas were able to travel long distance, while simultaneously demonstrating that there is a crucial level of local strategies to consider too.

Against this background, this article sets out to specify how similar the horned-helmet imagery is in material appearance, medium of presentation, and sociocultural context. What can be inferred about the chronology? Do these helmet figures spring from, or transmit, a shared idea at all? Why was the horned figure adapted into these three settings, but sparingly or not at all in others? The puzzling complexity surrounding these representations led us to perform the empirical comparative analysis presented below; and the results provide the scaffolding for a step-by-step discussion of the people and the processes behind the qualitative data patterns, at the local level as well as in the cross-linkages.

\section{Research and debates: an overview}

While previous studies have readily affirmed linkages between the imagery found on Sardinia and in southwestern Iberia, faraway southern Scandinavia is often mentioned only in passing ${ }^{17}$. Even though the research literature is vast, the relations between these three groups have not previously been investigated in a targeted manner to establish similarities and differences.

Although the Scandinavian horned-helmet representations stand out among the crowd of Nordic Bronze Age products, they are rather understudied as a group within a group: the Viksø helmets and the Grevensvænge figurines are often discussed with other similar representations within a universe of warriors and other figures ${ }^{18}$. In a recent fieldwork communiqué, Valentina Matta and colleagues $^{19}$ acknowledged a relationship between the Sardinian and the Scandinavian imagery, drawing on Helle Vandkilde's reconsideration of the Viks $\varnothing$ helmets ${ }^{20}$. Close similarities between the rock carvings of Tanum,

16 Kaul 1998, 277-284; Kossack 1954; Kristiansen/Larsson 2005, 306-319; Sprockhoff 1954.

17 For example Gonzalez 2018, 44-45; Norling-Christensen 1946a; 1946b; Thrane 1975; Vandkilde 2013.

18 Glob 1962, 1969; Kaul 1998; Norling-Christensen 1943; 1946a; Vandkilde 2013.

19 Matta et al. 2020.

20 Vandkilde 2013. 
Sweden, and the Iberian stelae have recently been noted ${ }^{21}$ while Alpine and Galician rock art may provide general matrix-like similarities that transcend these regions ${ }^{22}$. Richard J. Harrison ${ }^{23}$ recognised only a structural similarity between the horned-helmet representations of the Iberian stelae, the Sardinian bronzetti, and the Monte Prama sculptures, also in Sardinia. He mentions the Viks $\emptyset$ helmets fleetingly ${ }^{24}$, but argues against their potential Atlantic-Mediterranean footing and connects them instead to Central European crested helmets and to an innate Scandinavian tradition of metalworking. In this respect, Harrison follows Henrik Thrane, who stated ${ }^{25}$ that crested helmets have a wide distribution in Europe. It is indeed possible that that the helmets from Viksø were locally made, or at least reworked to fit local styles ${ }^{26}$.

Several studies deal with either the Sardinian or the Iberian depictions. Interrelationships are commented on now and again, recently by Ralph A. Gonzalez in a thorough study ${ }^{27}$. With regard to Iberia, Harrison published most of the c. 140 Iberian stelae ${ }^{28}$. He discussed the local context and provided a Mediterranean as well as Atlantic outlook. Several Spanish-language overviews and opinions also exist ${ }^{29}$. In Sardinia, the Nuragic bronze statuettes (henceforth bronzetti) have been intensively studied and their production, function, and context discussed. Approximately five hundred bronzetti exist, among which mostly the Uta-Abini group interests us here ${ }^{30}$. Supplementing this, the Monte Prama limestone giants are now also published ${ }^{31}$, although the site itself is still under excavation. It is now clear that horns in anthropomorphic and zoomorphic imagery have a deep ancestry, although it is accepted among researchers that Bronze Age versions often depict a cap or helmet to which the horns are attached, even in cases where this is not clear from the image, as on the Iberian stelae ${ }^{32}$.

Interpretations of the three geographical groups, separate or together, tend to follow parallel paths. In his western Mediterranean opus, Gonzalez ${ }^{33}$ pursues a generalised idea of intercultural communication increasing over time. Harrison concludes that a connection may have existed between the Iberian stelae and the hero cults emerging post-Bronze Age in Greece ${ }^{34}$. Vandkilde ${ }^{35}$ likewise has touched upon heroes and their cults against the background of Iron Age veneration of the Bronze Age past, traceable in Homer's epics and Hesiod's writings. There is a consensus that the Sardinian bronzetti were votive gifts offered at sanctuaries and were also connected with the sculptures at the Monte Prama heroön and with social change in Nuragic society post-1200/1100 BC ${ }^{36}$.

Emerging political power ${ }^{37}$ is a recurrent theme in the interpretations of the three groups, although social models based on tribal egalitarianism have also been advanced $^{38}$. Kristian Kristiansen and Thomas B. Larsson ${ }^{39}$ associate bulls' horns attached to the head of male figures with divinities and sacred rulership; they find parallels for the Scandinavian cases in Cyprus (the Enkomi bronze statuette of a god or prince standing on top of an oxhide ingot) and in the ancient Near East (the Naram-Sin victory stela $)^{40}$. Marta Diaz-Guardamino with colleagues ${ }^{41}$ advocates landscape approaches, using contextual and biographical analyses of the Iberian warrior stelae to point to the importance of 'persistent place'. Such a localisation approach is the anchor of connectivity studies: the stelae as memorials and as markers of ritual activities and territorial boundaries, as well as their proximity to copper ore (Sierra Morena) and road infrastructures, all resonate with Kristiansen's views ${ }^{42}$. The present contribution now adds to all this a comparative analysis of horned-helmet representations in the three zones, in conjunction with a scalar perspective on analysis and interpretation. Unfolding the horned-helmet imagery may reveal essential characteristics of LBA Europe at the threshold to the Iron Age. The Scandinavian case, located farthest away and rarely considered, merits particular consideration.

33 Gonzalez 2018.

34 Harrison 2004, 118-119; 176-177; compare also Pérez/López-Ruiz 2008, 485.

35 Vandkilde 2013.

36 Depalmas/Melis 2010, 171 Tab. 11,3; Lo Schiavo et al. 2009.

37 Cámara Serrano/Spanedda 2014; Diaz-Guardamino et al. 2019b; Diaz-Guardamino et al. 2019a; Ialongo 2013.

38 Gonzalez 2012; 2014; 2018, 349.

39 Kristiansen/Larsson 2005, 330-333.

40 See also Dikaios 1962; Schaeffer 1966; Thrane 1975.

41 Diaz-Guardamino et al. 2019b; Diaz-Guardamino et al. 2019a.

42 Kristiansen 1998, 157-160 figs 80-81. 
Tab. 1. Outline of the chronology. Light grey denotes a first phase of motif exchange; dark grey denotes a phase of expansive motif transfer in tandem with ritual consolidation.

\begin{tabular}{|c|c|c|c|c|c|c|}
\hline C. EUROPE & S. SCANDINAVIA & SW IBERIA & SARDINIA & GREECE & appr. BC & PHOENICIANS in the west \\
\hline Ha C-D & NBA VI & EIA & EIA 2 & Late Geometric-Archaic & 750 & \\
\hline Ha B3 & NBA V & FBA & EIA 1 & Early-Middle Geometric & 900 & entrepôts \\
\hline На B2 & NBA IV/V & & FBA 3 & Proto-Geometric & 1000 & \\
\hline Ha B1 & NBA IV & & FBA 2 & Sub-Mycenaean & 1100 & westward trading \\
\hline $\mathrm{Ha} \mathrm{A} 2$ & NBA III late & LBA & FBA 1 & LH IIIC & 1200 & \\
\hline $\mathrm{Br} \mathrm{D}-\mathrm{Ha} \mathrm{A} 1$ & NBA III & & LBA 2 & LH IIIB & 1300 & \\
\hline
\end{tabular}

\section{Scandinavian horned-helmet imagery in outline}

Apart from the two normal-sized helmets from Viksø (Sealand) and a horn from a similar helmet found in Grevinge (Sealand) ${ }^{43}$, the Scandinavian repertoire of hornedhelmet expressions consists of three sets of two figurines from Grevensvænge (Sealand) ${ }^{44}$, Fogdarp (Scania) $)^{45}$, and Kallerup (Thy, Jutland) ${ }^{46}$. Additionally, there are a pair of figures on a razor (Vestrup Mark, Jutland) ${ }^{47}$ and about forty images on rock in Bohuslän, western Sweden (SHFA) ${ }^{48}$. In total, fifty horned-helmet images have been recorded for this study in southern Scandinavia, either made in bronze or carved on rock, mostly the latter (Tab. 2). The motif favours iconically represented horned twin warriors.

Weaponry (especially oversized battle-axes with a distinctly splayed blade) and the horse-drawn ship are mandatory ingredients in the archetypal theme of the horned warrior twins. Variations are especially visible on the rock-carved scenes: a sheathed sword is obligatory, battle-axe, round shield, and spear are commonly depicted, and archery is sometimes present. The twin warrior figures are presented alone or, more rarely, among a group of warriors. Special females are affiliated and portrayed as powerful sacred beings (with large gold eyes, accentuated calf muscles), kneeling or shown as acrobats jumping the

43 Norling-Christensen 1943; 1946a.

44 For example Djupedal/Broholm 1953; Glob 1962; Thrane 1999.

45 Larsson 1974; 2017.

46 Photos of the Kallerup figurines are available on the website of Thy Museum. The website also describes basic find circumstances http:// museumthy.dk/nyheder/kallerupfundet.aspx; http.//museumthy.dk/ nyheder/kallerupfundet-paa-top-10.aspx.

47 Ahlqvist 2020b; Bradley 2006.

48 Ling/Bertilsson 1994. https://www.shfa.se/ length of a ship, or otherwise engaged, for example, in scenes of hieros gamos ${ }^{49}$. The oversized standing figure behind the twins on the Vestrup Mark razor is probably a woman ${ }^{50}$. The association of these various figures with the night and day of the solar cycle is evident ${ }^{51}$. The entire ensemble was apparently attached to a wooden ship model with the stallions at the ship's bows ${ }^{52}$.

Importantly, similar horns also occur attached to snakes and horses (in the Fårdal setup of figurines at Viborg, Jutland, for example) and to horse-headed gold bowls. Similarly, the blowing horns or lurs, always in doubles, can essentially be perceived as a parallel way of portraying the horned twins, who are in fact sometimes depicted playing the lur ${ }^{53}$. These representations multiply the actual number of horned creatures, evidently sharing in a context of sacredness. In many cases, just the paraphernalia of the twins occurs as an offering or imaging, with the rest of the assemblage likely implied, as pars pro toto ${ }^{54}$.

\section{Comparing chronology: coinciding trends towards politico-religious power (Tab. 1)}

The chronology may possibly be less secure than sometimes claimed ${ }^{55}$, and details are therefore debated ${ }^{56}$. Much knowledge is still based on typo-stylistic series and assem-

\footnotetext{
49 Kristiansen/Larsson 2005, figs 106; 160; 163. 50 Ahlqvist 2020b.

51 Kaul 1998, 2004.

52 Glob 1962.

53 Kristiansen/Larsson 2005, 318.

54 Fontijn 2020, 123 fig. 6,2; Kaul 2004.

55 See for example Harrison 2004, 13.

56 Brandherm 2008.
} 
blage combinations; ${ }^{14} \mathrm{C}$ ranges might be more robust. This applies, to differing degrees, to all three regions. Current knowledge nonetheless allows a number of chronological observations.

\section{Scandinavia}

The Scandinavian horned-helmet figures date to the Late Nordic Bronze Age, NBA IV-V. Each period is distinct regarding style and object types, albeit ${ }^{14} \mathrm{C}$ indicates a degree of overlap. The combined range of NBA IV and NBA V is $1100-750 \mathrm{BC}$, as demonstrated by good radiocarbon coverage among burials that have otherwise been dated typologically to one of these periods ${ }^{57}$. NBA IV, then, covers c. 1100-900 BC, and NBA V c. 900-750 BC. A period of transition 1000-900 BC should nonetheless be inserted ${ }^{58}$. Most horned-helmet figures in bronze belong typologically to NBA V, as especially made clear by the markedly splayed cutting edge and the sometimes rollededge corners of the large shafthole-axes.

The Vestrup Mark razor (cf. Fig. 3) with two horned warriors is often dated stylistically to NBA $\mathrm{IV}^{59}$, but the axes the warriors wield and the wavy snake-horse seem transitional to NBA V c. 1000-900 BC. Finally, in the Tanum rock art area, most images with horned figures are associated with NBA V ships, in accordance with Ling's ship typo-chronology ${ }^{60}$. An exception is the horned figures near an NBA IV ship at Bro Utmark 3 (SHFA) ${ }^{61}$. Horned figures on rock often carry round shields of Herzsprung type, or derivatives very similar to the pile of boss-decorated shields at Fröslunda, near Lake Vänarn, Sweden, which have a ${ }^{14} \mathrm{C}$ date around $800 \mathrm{BC}^{62}$.

Organic material from inside the horns of one of the Viksø helmets (B13552) was recently radiocarbon dated. The 20mg sample (laboratory sample identifier: MAMS42233) was pre-treated by the ABA-method (Acid/Base/ Acid) using washes of $\mathrm{HCl}, \mathrm{NaOH}$ and again $\mathrm{HCl}$ in order to remove contaminations caused by carbonates and humic acids. The remaining sample material was combusted in an elemental analyser and reduced to graphite using a commercially available graphitisation system (IonPlus, AGE3). Radiocarbon determination was performed at CEZA (Mannheim, Germany) using a MICADAS-type accel-

57 Olsen et al. 2011; Vandkilde et al. 1996.

58 Olsen et al. 2011, 268.

59 For example Ahlqvist 2020b.

60 Ling 2008, 99-105, fig. 7,35.

61 Ling/Bertilsson 1994. https://www.shfa.se/

62 Hagberg 1988; Larsson 2011. erator mass spectrometer (AMS) ${ }^{63}$. During measurement, the isotopic ratios of ${ }^{14} \mathrm{C} /{ }^{12} \mathrm{C}$ and ${ }^{13} \mathrm{C} /{ }^{12} \mathrm{C}$ from the sample, standards (Oxalsäure-II), blanks (phthalic acid) and control-standards (various IAEA standards) were measured. The dating results are reported as conventional ${ }^{14} \mathrm{C}$ dates, normalising to the standard delta ${ }^{13} \mathrm{C}$ value ${ }^{64}$ of $-25 \%$. The ${ }^{14} \mathrm{C}$ age of the organic remains inside the horn of helmet B13552 (years before present, i.e. 1950) was measured to $2791+/-21$ years BP, which results in possible calibrated calendar date ranges from 1006-857 BC (with 95,4\% probability) and 976-907 BC (with $68.2 \%$ probability), respectively. The terminus ante quem for the helmet's use before deposition is therefore 857-907 BC. Compared to the radiocarbon dates from cremated bones used by Jesper Olsen and colleagues ${ }^{65}$ (who defined the phase transition from period IV to V) the Viksø helmets should be placed at the end of NBA IV - or, more precisely, within the transition period to NBA V (Fig. 2).

In summary regarding the Scandinavian chronology: Most of the horned-helmet imagery of this region dates to traditional NBA V, 900-750 BC. However, an onset c. 1000 BC in late NBA IV is likely now supported by the AMS date of the Viksø helmet. A further factor is that the Nordic horned-helmet imagery coincides with most of the region's rich hoard depositions and rock art images, and also with the emergence of what we may term sanctuaries: in this case, open-air sacred places with institutionalised cults serving a larger area. The NBA V metalwork is distinguished by emblematic traits that can probably be interpreted as the brand of a new social regime backed by a mixture of political and religious power ${ }^{66}$.

\section{Sardinia}

Following Gonzalez ${ }^{67}$, the Uta-Abini group of bronzetti were produced 1200-950 BC and their deposition at sanctuaries probably extended beyond $950 \mathrm{BC}$ into the EIA. This first bronzetti tradition was succeeded by the so-called Mediterraneizzante group, 950-750 BC, which shows much less attention to warriorhood, while the horned-helmet figure disappears. There are few, if any, ${ }^{14} \mathrm{C}$ dates to rely on. The head of a horned-helmet archer was found in a LBA twelfth/eleventh-century BC stratum at Funtana Cob-

\footnotetext{
63 Kromer et al. 2013.

64 Based on Stuiver/Polach, 1977

65 Olsen et al. 2011.

66 Ahlqvist 2020a; Ahlqvist/Vandkilde 2018; Kristiansen 1998. 67 Gonzalez 2012, 2018.
} 


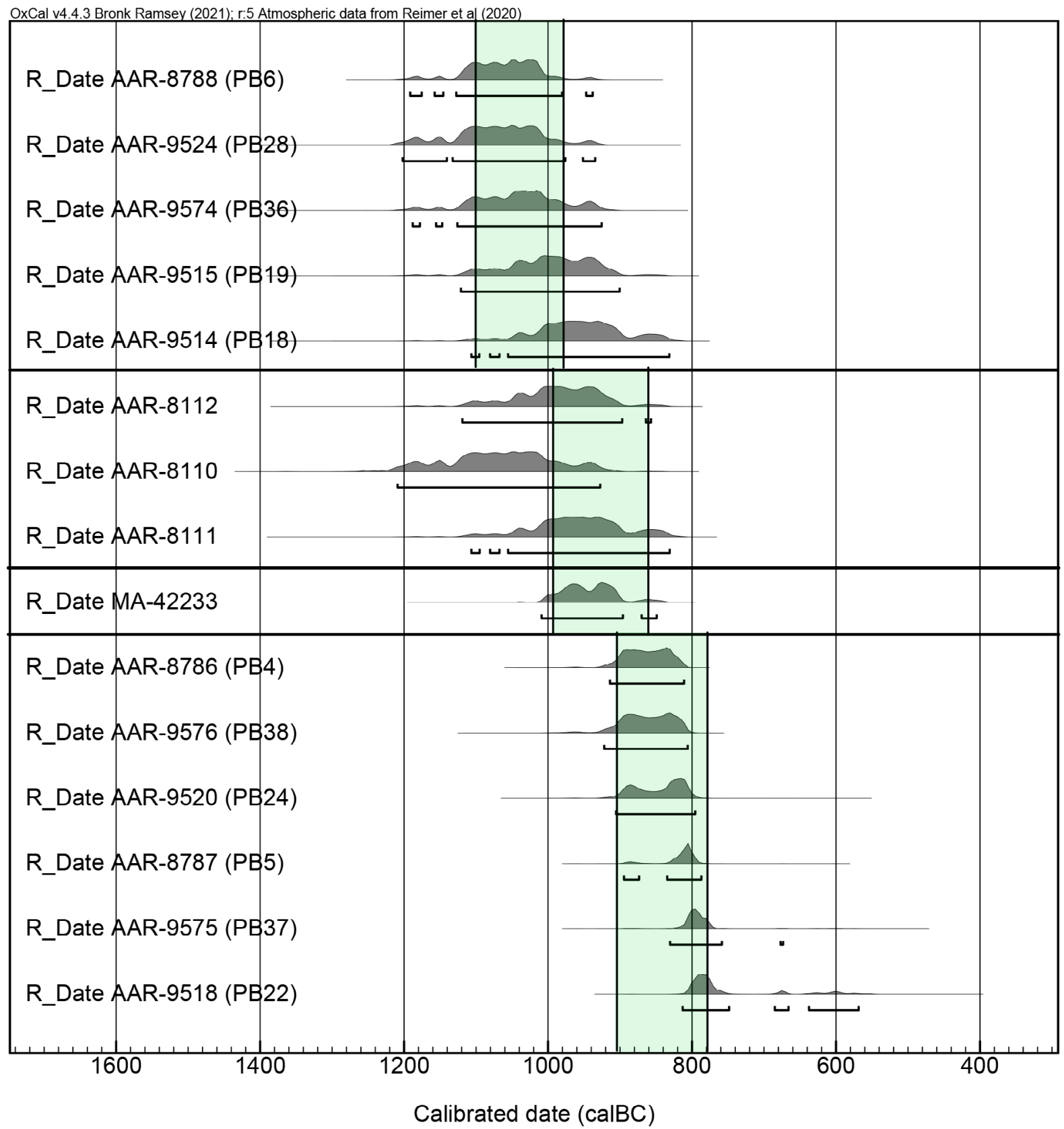

Fig. 2: Probability distribution of dating for the Viksø helmet (B13552) compared to radiocarbon ranges for bone and cremated bone from burial assemblages (Olsen et al. 2011) typologically dated to NBA IV and NBA V. The modelled multiple plot shows NBA IV as distinct from NBA V, but separated by the transition period also identified by Olsen et al. 2011. Horizontal black lines indicate the identified periods: NBA IV is presented by the ${ }^{14} \mathrm{C}$ dates of samples AAR-8788 to AAR-9514, while the transition period NBA IV/V is presented by the ${ }^{14} \mathrm{C}$ dates from samples AAR-8112 to AAR-8111. Here the Viksø helmet's AMS date shows the best fit. NBA V is presented by ${ }^{14} \mathrm{C}$ dates from samples AAR8786 to AAR-9518. Calibration was performed using the IntCal13 dataset (Reimer et al. 2013) and software OxCal 4.2 (Bronk Ramsey 1995).

erta-Ballao ${ }^{68}$. Gear affiliated with the Uta-Abini bronzetti supports the suggested date, and the gamma-hilted dagger, pistilliform sword, votive sword, and so-called Philistine crown support the LBA-FBA dating of the Uta-Abini group, which in its early appearance seems similar to so-called 'Sherden warriors' at Medinet Habu, Egypt, dated to 1176 $\mathrm{BC}^{69}$. Statue menhirs erected at south Corsican sanctuaries belong in the same category, even if such Bronze Age 
menhirs are peculiar to Corsica. In a limited number of the Corsican cases, notably at Filitosa and Cauria, horns seem to have been attached to a cavity on each side of the stone warrior's head/helmet, often dated c. 1300-1100 BC and sometimes coupled to Sardinian warriors ${ }^{70}$.

The so-called 'Round-Eye Artist' is particularly associated with the giant Monte Prama sculptures of warrior archetypes. The Uta-Abini bronzetti, especially those made by the Round-Eye Artist, can plausibly be regarded, following Gonzalez ${ }^{71}$, as the prototypes of the Monte Prama sculptures, a development that can be dated to the ninth/ eighth centuries $\mathrm{BC}$ because the cist burials beneath were constructed 941-838 cal. BC (sampled on bone and other materials $)^{72}$. Sardinian bronzetti of the Uta-Abini type occasionally occur outside the island of Sardinia on the Italian mainland in tombs, for instance at Vulci c. $800 \mathrm{BC}^{73}$.

In summary, regarding the Sardinian chronology: The horned-helmet figure materialises prominently among the bronzetti 1200-750 BC; from c. $900 \mathrm{BC}$, it is additionally made in stone. The sequence of horned-helmet representations is consistent with long-term changes beginning c. 1200 BC as the Nuragic culture entered its final stage. The precise development is debatable, but may be described as follows: An altered demography and trends towards centralisation seem to be indicated and these trends may be visible in the now fewer and often enlarged Nuraghe settlements that commemorate the central Nuraghe towers as ancestral ${ }^{74}$. These hubs seem intricately connected with the central sanctuaries that were on the rise during this period, when Sardinia emerges as a crossroads for metal production and trade in the greater Mediterranean between the Levantine east and the Balearic and Iberian west. At the end of the ninth century BC, Sardinia saw the first Phoenician entrepôts; these had been preceded by Levantine (Philistine or early Phoenician) quests for silver as early as $1100 \mathrm{BC}^{75}$.

\section{Iberia}

The Iberian stone stelae form a long chronological line. The question that interests us here is the chronological position of the horned-helmet figure occurring on some

70 Gonzalez 2012, 100-102; 2018, 276; 284-290; Leandri et al. 2015 (refers only to the Medinet Habu relief).

71 Gonzalez 2012, 95-96.

72 Lai et al. 2014; Tronchetti 2014; Usai 2015, 110.

73 Gonzalez 2012, 98.

74 For example Perra 2017; Ugas 2014; Usai 2015.

75 For example Bartoloni 2017, 33; Ben-Yosef 2019. of the warrior stelae. Differing interpretations ${ }^{76}$ may be attributable to difficulties posed by matching the gear on the images with extant object types. Additionally, object assemblages like that at Ría de Huelva include early as well as later types, with quite a wide ${ }^{14} \mathrm{C}$ range between 1100 and $900 \mathrm{BC}^{77}$. Herzsprung and other round-shield types, also depicted on the stelae, have a long production and circulation time, beginning c. 1250/1200 BC and continuing post-900 $\mathrm{BC}^{78}$.

There is a consensus on major developments here, including placing anthropomorphic stelae in the later part of the sequence: the first stelae only depict the warrior's gear, but over time the warrior himself is allowed into the scene and gradually grows in size and centrality. Following Diaz-Guardamino and colleagues ${ }^{79}$, warrior stelae groups A, $\mathrm{B}$ and $\mathrm{B}+\mathrm{O}$ develop simultaneously during the twelfth to tenth centuries BC; but only group A, with human figures depicted together with weaponry and accessories, continues into the ninth to eighth centuries BC (EIA). This approximate range is supported by a few stratified finds on stelae, and by ${ }^{14} \mathrm{C}$ sequences of mortuary monuments at sites with stelae (i. e. not directly by the stelae). A Huelva-type sword (1130-1050 BC) was also found near the anthropomorphic warrior stela at Almargen ${ }^{80}$. Within the total span of 1250/1200-750 BC, Harrison considers horned figures to be a historically late development. Dirk Brandherm ${ }^{81}$ likewise argues that the stelae with human figures, some of them horned, represent the final stage of Iberian stelae; based on object chronologies, he states that horned headgear was added to the repertoire no later than the end of the eleventh century BC. By comparison, Sebastián C. Pérez and Carolina López-Ruiz ${ }^{82}$ favour the ninth to eighth century $\mathrm{BC}$ for several of the anthropomorphic stelae with horned-helmet warriors, basing this on a number of new-found stelae with secure context ${ }^{83}$. Bronze figurines in Iberia are a very late phenomenon 800-500 BC, 'oriental' in style and lacking horns ${ }^{84}$.

In summary, regarding the Iberian chronology: Stelae with horned-helmet warriors are specific to southwestern Iberia. The first stelae with horned-helmet images may have appeared around 1200/1100 BC, but continued in

76 Brandherm 2008 versus Pérez/López-Ruiz 2008.

77 Diaz-Guardamino 2019b, 13-14 fig. 8; Harrison 2004, 14.

78 Harrison 2004, 124-134; Uckelmann 2012.

79 Diaz-Guardamino et al. 2019b, 12.

80 Diaz-Guardamino et al. 2019b; Diaz-Guardamino et al. 2019a.

81 Brandherm 2008, 482.

82 Pérez/López-Ruiz 2008.

83 See also Murillo-Redondo et al. 2005.

84 Gonzalez 2018, 259-261. 
production and use until c. $800-750 \mathrm{BC}$. Importantly, the sequence coincides with the emergence both of what might be seen as political landscapes in the region and intensified metal-led activities, these last in part tied to Phoenician activities from 1000 BC. Notably, the anthropomorphic warrior stelae of group A occur distributed on either side of the ore-rich Sierra Morena mountain range. Some sites with stelae boast stone hammers, for metal crushing, as well as slags ${ }^{85}$.

\section{Comparative chronology according to current knowledge}

Contemporaneity can be observed between the dates of horned-helmet representations in Scandinavia (1000-750 BC), Iberia (1200/1100-750 BC), and Sardinia (1200-750 $\mathrm{BC})$. The appearance and evolution of these representations are contingent on societal change and, arguably, rising political forms of power in all three zones. From $1200 / 1100$ BC, the focus of metal-trading had started moving westward in the Mediterranean Sea, highlighting Sardinia and the Iberian southwest, two zones that are naturally rich in metals. Scandinavia by comparison was completely dependent on imported copper.

In all three zones, the horned-helmet motif was longlived, probably with shifting meanings over time but with the $900-750 \mathrm{BC}$ period especially formative. When considering this motif, current chronological data suggests that Sardinia and Iberia were especially connected 1200-1100 $\mathrm{BC}$ at the transition to the FBA and onwards. The Scandinavian zone was a latecomer, perhaps joining the network $1000 \mathrm{BC}$ at the earliest, then more substantially from c. 900 BC. At the time Monte Prama was built, the Phoenicians were consolidating their silver-led trading activities by establishing entrepôts throughout the western Mediterranean, with the Atlantic metal trade blooming correspondingly ${ }^{86}$. This is the period when Scandinavian and Sardinian imagery in particular show similarity.

85 Diaz-Guardamino et al. 2019b, fig. 9; Diaz-Guardamino et al. 2019a, fig. 16.

86 Cleary/Gibson 2019, 105-109 fig. 4,19; Kristiansen 1998, 144-160, fig. 63.

\section{Comparing appearances and media of representation}

The comparative analysis rests on a semi-quantitative analysis of the figurative components in the three zones, including details of helmets, horns, and immediate surroundings. In total, 31 major figurative traits have been identified (Fig. 3, Tab. 2). These results are discussed and contextualised below through detailed qualitative comparison. Central features in the three zones have been evaluated in search of a shared or even systemic structure or carrying idea, as well as local foundations. Key aspects of the material appearance of the horned-helmet imagery, as well as its associations and the medium of representation, serve as a platform for further explorations into the characteristics and their associations.

\section{Semi-quantitative analysis and result}

The analytic procedure followed seeks to bring to the fore similarity and difference for the major figurative traits in all three geographical zones. Component variables comprise, first, material appearance - horns and helmet details, rendering of eyes, oversizing, twinness, phallic state, fellowships (groups), narratives/archetypes, weaponry, vehicles, animals/hybrids. Component variables also comprise, second, the media of representation - bronze figurines, stone sculpture, and images on stelae and rock. A simple quantitative scoring has been combined with observations stating whether a particular trait is absent (0) or recorded as merely present (1), well-known (2), or dominant (3). While this may lack absolute precision, it provides a visual overview of degrees of similarities and difference when comparing the three zones pairwise (Fig. 4A-C). Thereby, we gain insight into local as well as shared characteristics. It should be noted that the chosen medium of representation influences how horns, eyes, and warrior height are technically mediated by the artist to the onlooker. Thus stone and bronze are opposed from the outset. Some systemic traits are shared across the regions, notably oversize in whole bodies, body parts, and in weapons. A further systemic shared feature is that horned-helmet warriors seemingly form part of a community and a narrative, and that the horned-helmet warrior is represented as the central actor in this narrative. Various weapons, vehicles, and animals appear across the zones, with local preferences. Sword and round shield, however, are fully shared. 

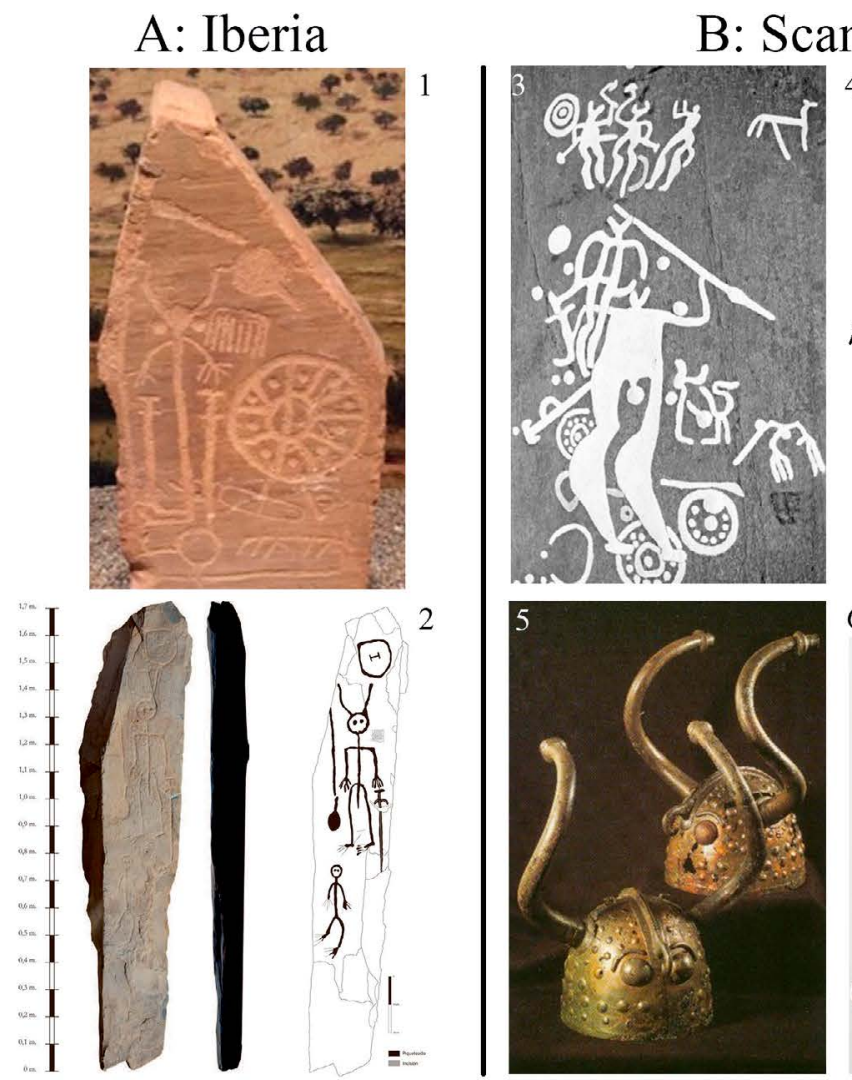

\section{ndinavia}

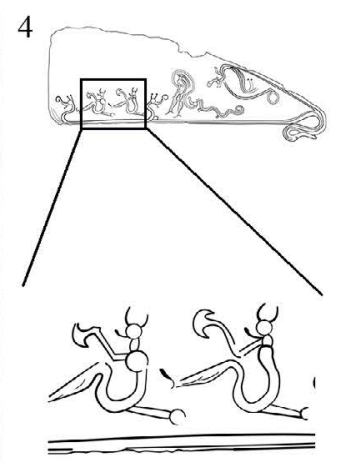

6

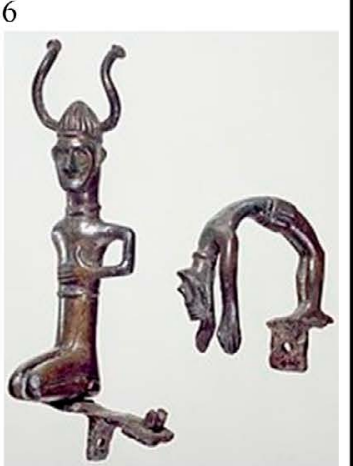

\section{C: Sardinia}

7

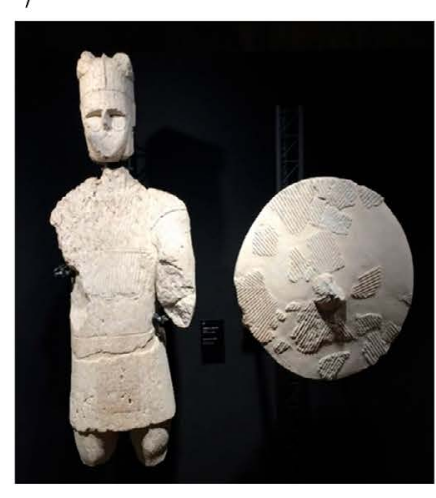

8

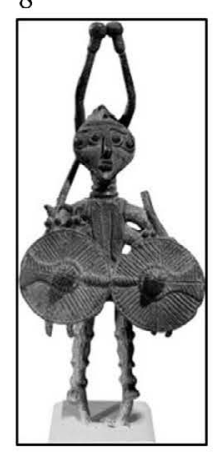

9

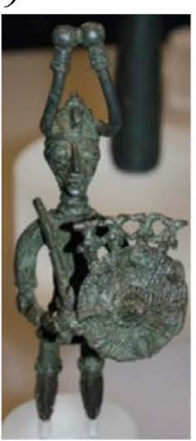

Fig. 3: Collage of horned-helmet presentations. A. Iberia: 1. El Viso I, Cordoba, H. $121 \mathrm{~cm}$ (H. Vandkilde photo, Museo Arqueológico Nacional, Madrid), 2. Esparragosa de Lares, Badajoz, H. 176 cm (Pavón Soldevilla/Duque Espino 2010, Fig. 4); B. Scandinavia: 3. Lövsåsen Tanum SHFA id 164 (Ling/Bertilsson 1994), 4. Vestrup Mark razor with miniature image of the twins and female (after Ahlqvist 2020b, fig.10), 5. Viksø helmets, Sealand (courtesy of the National Museum of Denmark, picture: Lennart Larsen under a CC BY-SA 4.0 license), 6. two preserved statuettes from Grevensvænge, Sealand, horned twin and female acrobat, probably originally attached to a wooden model ship (courtesy of the National Museum of Denmark, picture: Lennart Larsen under a CC BY-SA 4.0 license); C. Sardinia: 7. Sculpted horned-helmet warrior from Monte Prama, originally c. $2 \mathrm{~m}$ tall, horns removed in antiquity (H. Vandkilde photo, Museo Archeologico Nazionale di Cagliari), 8-9. Bronzetti made by the so-called Round-Eye Artist of the Uta-Abini tradition (Lilliu 1966). Not to scale.

Scandinavia and Sardinia (Fig. 4A) share miniature figurines in bronze as well as large figures made in/on stone. The way in which helmets and horns are represented is also similar. There are, furthermore, close similarities in how eyes are rendered as round and protruding, or drawn as a circle with a central circle or dot. The eye is often shown inside a recess in the face. Both areas have a preference for animal-headed ships. Among the 31 traits, 15 compare as dominant or present/well-known in both areas.

Scandinavia and Iberia (Fig. 4B) share horned-helmet figures on stelae/rock, with notable similarity in how the horns are shown standing upright and turned. Other helmet types occur in the vicinity of the horned-helmet figure. Furthermore, horned-helmet figures occur mostly/ often as pairs (conceptualising the twin motif), and the spear, together with horse (chariot), is a favourite. Among the 31 traits, 12 compare as dominant or present/wellknown in both areas.
Sardinia and Iberia (Fig. 4C) mostly share overarching features that glue all three zones together. Archery is a favourite in both zones. In this case, the analytic outcome has been impacted by the lack of bronze miniatures in Iberia and lack of stelae in Bronze Age Sardinia ${ }^{87}$. Among the 31 traits, nine compare as dominant or present/wellknown in both areas.

The analytic result demonstrates patterned similarity and difference between the three zones with horned-helmet imagery. Observed interrelationships are visualised as a network (Fig. 4D), serving to examine the degree of connectivity between the three zones' imagery. It is evident that the similarity between Scandinavia and Sardinia is,

87 Chalcolithic menhirs depicting horned headdress and weapons are well known https://www.menhirmuseum.it/fine-del-mondo-deimegaliti. 
Tab. 2. A. Overview of data collected for the purpose of this article. B. Selected empirical traits.

\begin{tabular}{|c|c|c|c|}
\hline HORNED-HELMET FIGURES & $\begin{array}{l}\text { min. number of } \\
\mathrm{H}-\mathrm{H} \text { figures }\end{array}$ & Remarks about $\mathrm{H}-\mathrm{H}$ background & Key references \\
\hline Scandinavia (S 40) & & & $\begin{array}{l}\text { Kaul 1998, 2004, 2005; Kristiansen \& } \\
\text { Larsson 2005 }\end{array}$ \\
\hline Viksö helmets & $2(3)$ & $\begin{array}{l}\text { no other metal helmets (however one } \\
\text { horn from Grevinge) }\end{array}$ & $\begin{array}{l}\text { Norling-Christensen 1946; Vandkilde } \\
2013\end{array}$ \\
\hline Vestrup Mark razor & 2 & $\begin{array}{l}\text { several non-anthropomorphic picto- } \\
\text { rial razors from (male) cremations }\end{array}$ & Bradley 2006; Ahlqvist 2020b \\
\hline Figurine anthropomorphs & 6 & $\begin{array}{l}\text { 5-10 other-type anthropomorphs } \\
\text { (often decontextualised) }\end{array}$ & $\begin{array}{l}\text { Glob 1962; http://museumthy.dk/ } \\
\text { nyheder/kallerupfundet.aspx }\end{array}$ \\
\hline Rock-carved figures Tanum & 39 & $\begin{array}{l}\text { several anthropomorphic images on } \\
\text { rock }\end{array}$ & $\begin{array}{l}\text { Ling 2008; SHFA - Svenskt Hällrist- } \\
\text { ningsForskningsarkiv }\end{array}$ \\
\hline Sardinia (S 107) & & & Lilliu 1966 \\
\hline $\begin{array}{l}\text { Uta Abini bronzetti with } \\
\text { horns }\end{array}$ & 95 & c.200 Uta Abini-type figurines in total & Gonzalez 2012, 2018; \\
\hline Monte Prama & 12 & 29 warriors/males aligned & Bedini et al. 2012; Minoja et al. 2015 \\
\hline Iberia (S 41) & & & $\begin{array}{l}\text { http://www.estelasdecoradas.es/ } \\
\text { paginas/que_son.htm }\end{array}$ \\
\hline $\begin{array}{l}\text { Horned-helmet warriors on } \\
\text { stelae }\end{array}$ & 41 & $\begin{array}{l}140 \text { stelae recorded of all variants } \\
(A, B, B+0)\end{array}$ & $\begin{array}{l}\text { Harrison 2004; Diaz-Guardamino } \\
\text { 2014, 2019a-b; Gonzalez } 2018\end{array}$ \\
\hline
\end{tabular}

B

\begin{tabular}{llll}
\hline HORNED-HELMET FIGURES & transport vehicles & population \& gender & therianthropic/zoomorphic \\
\hline Scandinavia & ship, horse, chariot & warriors, females, unspecified others & common/common \\
\hline Sardinia & ship (navicelle) & $\begin{array}{l}\text { warriors, multiple gendered identi- } \\
\text { ties, roles, situations }\end{array}$ & exist/common \\
\hline Iberia & cart, horse, chariot & warriors, females, unspecified others & rare/common \\
\hline
\end{tabular}

overall, strong. However, the Scandinavian rock carvings share common features especially with the Iberian stelae. Below, the matrix expressed in Figure 4 is elaborated by an in-depth comparative analysis contextualising the observations. A scalar dialectic has been revealed, which calls for further analysis and explanation.

\section{Horned-helmet warriors among other archetypes in an ideal community}

In all three zones, the distinct appearance of the hornedhelmet warriors communicates exclusivity, above all through the horns, but also through other traits. The appar- ent gender of our figure is male, as expressed sometimes by phallic imagery (i.e. intersecting with biological sex) as well as by associated material culture depicted alongside the anthropomorphs on stelae and rock panels. Within and across the zones, the horned-helmet figures refer not only to one another, but also to a wider community.

The 40 Scandinavian horned-helmet warriors reside within a wider community of anthropomorphic figures, both in bronze and on rock, including other males without horned insignia, females, and smaller, more ordinary-looking figures - all affiliated with the perpetual nature of the solar cycle indicated by circular imagery. A specific corpus of weapons, symbols, and vehicles is added.

Similarly, in Iberia, 41 horned-helmet figures are identifiable on warrior stelae in a total record of 140 stelae so far. In addition to horned-helmet warriors, the anthro- 


\begin{tabular}{|c|c|c|c|}
\hline & COMPONENT VARIABLES & Scandinavia & Sardinia \\
\hline & upright standing horns & 3 & 3 \\
\hline 2 & flat horns close to head & 2 & 2 \\
\hline & turned horns & 3 & 3 \\
\hline & horns with end knobs & 2 & 2 \\
\hline & horned helmet with crest & 1 & 3 \\
\hline & other helmet types & 2 & 2 \\
\hline & centrality of horned-helmet figure & 3 & 3 \\
\hline 8 & protruding round eye or recessed circular eye with centı & 3 & 3 \\
\hline 9 & figurines in bronze & 2 & 3 \\
\hline 10 & image on stelae or rock & 3 & 0 \\
\hline 11 & sculptured warriors & 0 & 2 \\
\hline 2 & oversized figures & 2 & 2 \\
\hline 3 & oversized body parts and/or weaponry & 3 & 3 \\
\hline 14 & twins & 3 & 1 \\
\hline 5 & warrior fellowships & 1 & 2 \\
\hline 6 & phallic warriors & 2 & 0 \\
\hline 7 & narrative involving achetypes & 3 & 3 \\
\hline 8 & sword & 3 & 3 \\
\hline 19 & roundshield & 2 & 3 \\
\hline 20 & spear & 2 & 1 \\
\hline 21 & battle-axe & 3 & 0 \\
\hline 22 & dagger & 0 & 3 \\
\hline 23 & archery & 1 & 3 \\
\hline 24 & cart/chariot & 1 & 1 \\
\hline 25 & ship/boat & 3 & 2 \\
\hline 26 & body grooming tools & 0 & 0 \\
\hline 27 & horse & 3 & 0 \\
\hline 28 & dog & 1 & 1 \\
\hline 29 & deer/ram/cattle & 1 & 3 \\
\hline 30 & armour/leggings & 0 & 3 \\
\hline 31 & therianthropic hybrids in vicinity & 3 & 1 \\
\hline
\end{tabular}

\begin{tabular}{|c|c|c|}
\hline COMPONENT VARIABLES & Sardinia & Iberia \\
\hline$1 \longdiv { \text { upright standing horns } }$ & 3 & 3 \\
\hline 2 flat horns close to head & 2 & 0 \\
\hline 3 turned horns & 3 & 3 \\
\hline 4 horns with end knobs & 2 & 1 \\
\hline 5 horned helmet with crest & 3 & 0 \\
\hline 6 other helmet types & 2 & 3 \\
\hline 7 centrality of horned-helmet figure & 3 & 3 \\
\hline 8 protruding round eye or recessed circular eye with centr & 3 & 0 \\
\hline 9 figurines in bronze & 3 & 0 \\
\hline 10 image on stelae or rock & 0 & 3 \\
\hline 11 sculptured warriors & 2 & 0 \\
\hline 12 oversized figures & 2 & 1 \\
\hline 13 oversized body parts and/or weaponry & 3 & 2 \\
\hline 14 twins & 1 & 2 \\
\hline 15 warrior fellowships & 2 & 1 \\
\hline 16 phallic warriors & 0 & 1 \\
\hline 17 narrative involving achetypes & 3 & 2 \\
\hline$1 8 \longdiv { \text { sword } }$ & 3 & 3 \\
\hline 19 roundshield & 3 & 3 \\
\hline 20 spear & 1 & 3 \\
\hline 21 battle-axe & 0 & 0 \\
\hline 22 dagger & 3 & 1 \\
\hline 23 archery & 3 & 3 \\
\hline$2 4 \longdiv { \text { cart/chariot } }$ & 1 & 3 \\
\hline 25 ship/ boat & 2 & 0 \\
\hline 26 body grooming tools & 0 & 3 \\
\hline$2 7 \longdiv { \text { horse } }$ & 0 & 3 \\
\hline 28 dog & 1 & 2 \\
\hline 29 deer/ram/cattle & 3 & 1 \\
\hline 30 armour/leggings & 3 & 1 \\
\hline 31 therianthropic hybrids in vicinity & 1 & 0 \\
\hline
\end{tabular}

pomorphic group of stelae includes warriors wearing a crested or pointed conical helmet (sometimes combined on the same stela with the horned individual highlighted) in addition to smaller, anonymous-looking figures, including children and (it is assumed) women wearing a diadem or crown headdress. Like the Scandinavian figurines and rock carvings, some of the Iberian scenes appear as a narrative $^{88}$. Both zones depict the horns in the same manner,

\begin{tabular}{|c|c|c|c|}
\hline & COMPONENT VARIABLES & Scandinavia & Iberia \\
\hline & upright standing horns & 3 & 3 \\
\hline & flat horns close to head & 2 & 0 \\
\hline & turned horns & 3 & 3 \\
\hline & horns with end knobs & 2 & 1 \\
\hline & horned helmet with crest & 1 & $\mathbf{0}$ \\
\hline 6 & other helmet types & 2 & 3 \\
\hline 7 & centrality of horned-helmet figure & 3 & 3 \\
\hline 8 & protruding round eye or recessed circular eye with cent & 3 & 0 \\
\hline 9 & figurines in bronze & 2 & $\mathbf{0}$ \\
\hline 0 & image on stelae or rock & 3 & 3 \\
\hline 1 & sculptured warriors & $\mathbf{0}$ & 0 \\
\hline 2 & oversized figures & 2 & 1 \\
\hline 3 & oversized body parts and/or weaponry & 3 & 2 \\
\hline 4 & twins & 3 & 2 \\
\hline 5 & warrior fellowships & 1 & 1 \\
\hline 6 & phallic warriors & 2 & 1 \\
\hline 7 & narrative involving achetypes & 3 & 2 \\
\hline 8 & sword & 3 & 3 \\
\hline 9 & roundshield & 2 & 3 \\
\hline 0 & spear & 2 & 3 \\
\hline 1 & battle-axe & 3 & 0 \\
\hline 2 & dagger & $\mathbf{0}$ & 1 \\
\hline 3 & archery & 1 & 3 \\
\hline 4 & cart/chariot & 1 & 3 \\
\hline 5 & ship/boat & 3 & 0 \\
\hline 6 & body grooming tools & $\mathbf{0}$ & 3 \\
\hline 7 & horse & 3 & 3 \\
\hline 8 & dog & 1 & 2 \\
\hline 9 & deer/ram/cattle & 1 & 1 \\
\hline 0 & armour/leggings & $\mathbf{0}$ & 1 \\
\hline 1 & therianthropic hybrids in vicinity & 3 & 0 \\
\hline
\end{tabular}

Fig. 4A-C: Cross-zone comparison between horned-helmet imagery employing semi-quantitative scoring of 31 component variables in the three zones: Variable absent 0 , variable present 1 , variable well-known 2, and variable dominant 3 . The matrix of similarity and difference is visualised through colours. Yellow shows consistent systemic traits shared by all three zones; blue shows distinct features shared between Scandinavia and Sardinia (A), between Scandinavia and Iberia (B), and between Sardinia and Iberia (C) respectively.

and from the scenes depicted it also appears that horned figures occur as the central and dominant component and that they are sometimes staged within a well-known narrative, a repetitive prescribed scheme.

In Sardinia, of the 200 Uta-Abini anthropomorphic figurines, about half are warriors, most of whom wear horned helmets ${ }^{89}$. To these can be added 12 warriors/ archers with horned headgear among the Monte Prama 


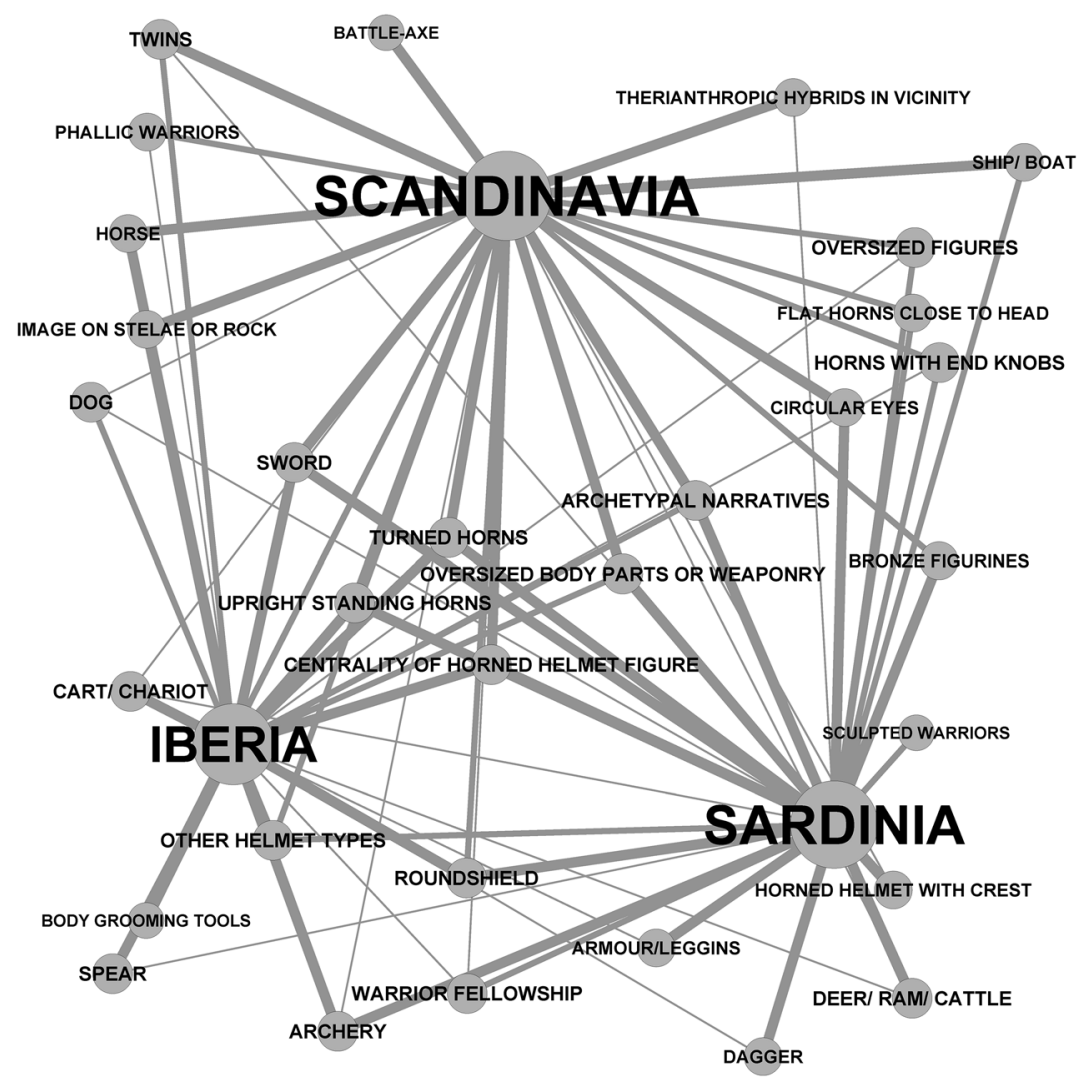

Fig. 4D: Degree of connectivity of the variables presented in Figs. 4A-C. Network Analysis (NA) is a useful tool for visualising common traits among the three regions at distinct levels. In the NA diagram, the elements common to all three areas are located in the centre of the network, while the less common, or variables shared by only two of the three regions, are located at the periphery of the network. The intensity of the connections is expressed through different shades of grey. Darker (thicker) lines indicate strong connections or shared elements, whereas lighter (thinner) lines means few elements in common, i. e. weak ties. The software used for the NA is Gephi (Force Atlas the algorithm).

crowd of 29 males, accompanied by 16 Nuraghe models of limestone ${ }^{90}$. The bronzetti in particular represent a rich world of several archetypal identities, signified through specific material appearances - female and male genders, children, and subdivisions of warrior males - along with a standard panoply of objects and vehicles for transport. Monte Prama, by comparison, depicts a world of exclusively male archetypes, already known en miniature in bronze, and all of them participants in one or several interrelated narratives.

Although the number of horned representations per region differs, with the largest number of specimens in Sardinia (Tab. 2), it is striking that in all three zones, the horned-helmet warriors stand out within a population of female or male companions. Both locally within each zone and transversely across them, the horns signify the potency of the helmet wearer, the quintessential warrior.
In addition, there are vehicles for transport, chariots or ships, various kinds of gear for war, and several species of animals. Altogether, it seems we are presented with an ideal society composed of archetypes ${ }^{91}$. Both within and across zones, the horned-helmet figures refer not only to each other, but also to a community of human-like and animal beings, as well as a familiar panoply of objects. The Sardinian community is the most complex and varied of the three cases of an archetypal narrative.

\section{Helmets, weaponry, and other items}

In the medium of bronze, helmet appearance is strikingly similar in Sardinia and Scandinavia, with a similar variation range in terms of length, turn, and the position of the horns on the helmet. Frequently occurring are short, 

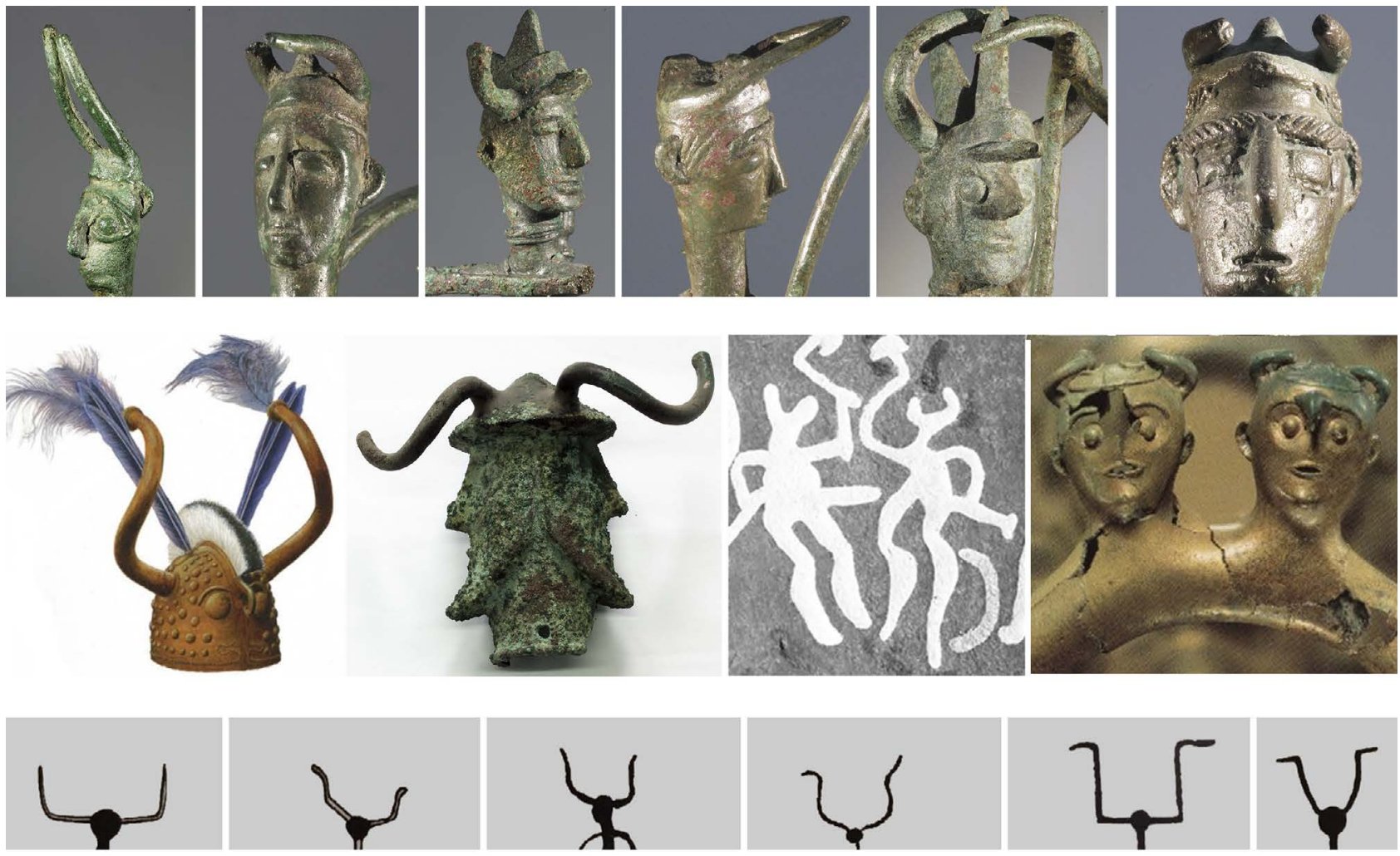

Fig. 5: Ways of representing the helmet horns in the three zones. Upper row: Sardinian bronzetti (photo: H. Nørgaard photo with permission by Museo Archeologico Nazionale di Cagliari). Middle row: Scandinavian figures from left: Viksø reconstructed (Kaul 2010; drawing Thomas Bredsdorff, National Museum of Denmark), Kallerup, Thy (photo: H. Nørgaard by courtesy of Museum Thy), rock carvings from Hede Kville, Tanum (SHFA: Ling/Bertilsson 1994, picture Åke Fredsjö 1973 under a CC BY-SA 4.0 license) and Fogdarp in Scania (after Larsson 1990). Lower row: Iberian horned helmets from stelae (based on Harrison 2004). Not to scale.

stubby horns with a forward cline close to the head, long horns standing erect, and the ends of horns sometimes sealed with distinct knobs. Stubby, forward-pointing horns occur on several of the Sardinian bronzetti and on the Scanian Fogdarp twins. Sardinia has the largest variation range of the three zones, including unique versions with longhorns pointing in different directions (Fig. 5). The Iberian stelae and the Tanum rock imagery of horned creatures are not devoid of similarity, however: horns always stand erect and may turn in various directions, and their more stereotypical appearance seems to have been dictated by the stone medium rather than stylistic preference. It is notable that the combination of crest and horns on the Viksø helmets matches the Sardinian bronzetti helmets ${ }^{92}$ (Figs 3; 5; 7). The Sardinian helmets of Uta-Abini style, which usually incorporate horns, sometimes supplement the horns with special effects that point forwards or backwards. This compares with bird feathers inserted on the Viksø helmets on either side of the crest ${ }^{93}$. Turned horns occur across all three zones.

Body aesthetics are priorities in all three zones, although only in Iberia are the warrior's grooming tools depicted in addition to jewellery and even weights and lyres. While all weapon types are associated with the horned-helmet warriors, the sword is ubiquitous across all three zones. The extra-large battle-axe is seemingly standard gear for the figurine Nordic twins; on the rock carvings, round shield and spear are frequent in addition, and even archery is mastered by the horned warrior. This matches very well with Sardinia and Iberia, although in those two regions the imagery of archery and archers is much more frequent than in Scandinavia. The weaponry of the LBA world is often classifiable into types of supraregional coverage, although localised types and preferences are also on the agenda. 

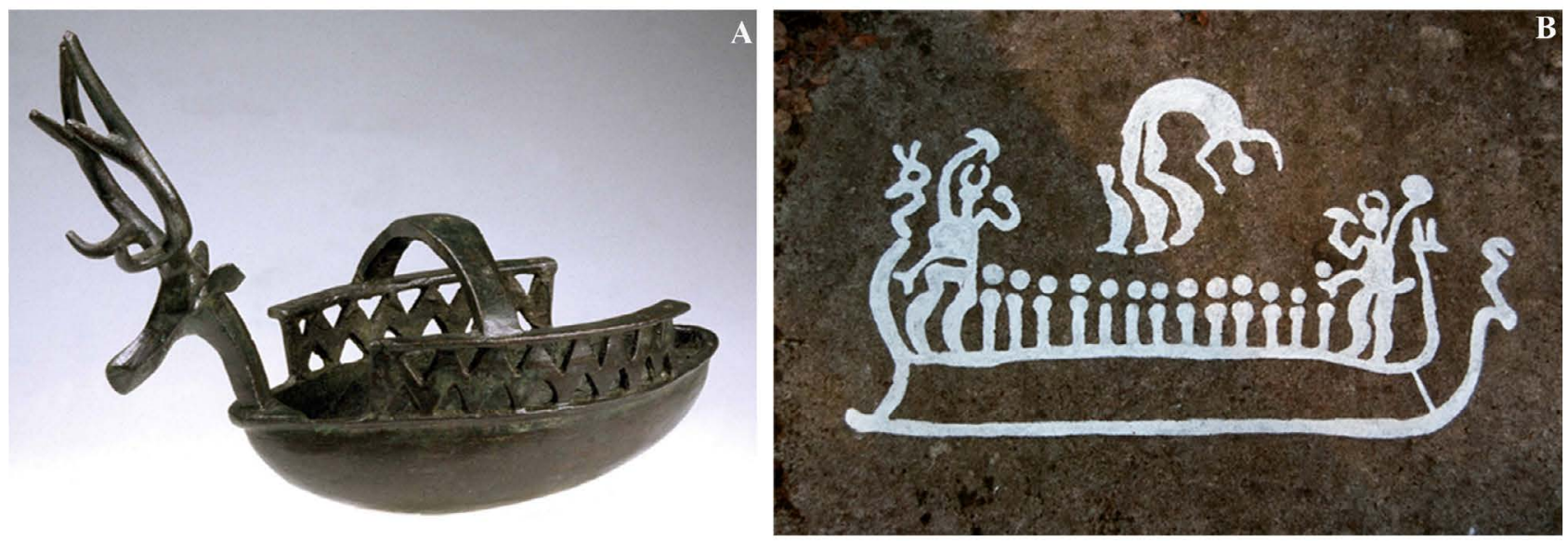

Fig. 6: A. Sardinian bronzetto boat (navicelle) with bull/ram-headed bow and birds onboard (photo: V. Matta; Museo Archeologico Nazionale di Cagliari), 1000-700 BC. B. Nordic horse-headed ship from Sotetorp in Tanum (SHFA; Ling/Bertilsson 1994, picture G. Milstreu 2006 under a CC BY-SA 4.0 license), 900-750 BC. Note the aggrandised horned twins, female acrobat, and anonymous crew (of newly dead?). Not to scale.

Armour and leggings are common in Iberia and Sardinia, but evidently absent in Scandinavia ${ }^{94}$. On rock, the warriors appear to be naked, and now and again phallic. The latter feature sometimes also appears on Iberian stelae to indicate the sex of the horned figure, e. g. Esparagosa de Lares II, Extremadura ${ }^{95}$ (see Fig. 3).

The ship is conspicuously absent from the Iberian representations, which favour chariots and horses. In Sardinia, it is the horse that is absent; instead, the 146 bronzetti boats - navicelle - often have bull- or deer-shaped sterns, sometimes reinforced by birds (Fig. 6) ${ }^{96}$. This matches the ever-present horse-prowed ship in Scandinavia, where a swan or monstrous beings sometimes substitute the horse, as exemplified by the two ships (one for each twin) depicted on the Viks $\varnothing$ helmets ${ }^{97}$. Overall, the pre-eminence of the bronzetti boats underlines the sea-going domain in Nuraghe society, comparable to the numerous ship carvings in maritime Scandinavia (where, however, chariots also occur on rock ${ }^{98}$. The Nordic materialisations of the twins are, as mentioned, almost inevitably associated with a horse- or swan-pulled ship.

\section{Twin or double representations}

The iconic Nordic identical twins appear to be deeply entrenched in locally or regionally rooted cosmology and beliefs ${ }^{99}$. It is thought-provoking, however, that doubles or mirror-images of warriors with and without horned helmets are depicted in all three zones. Representation in doubles (four eyes, four arms, and a double-up of weaponry) occurs among the Sardinian bronzetti ${ }^{100}$ (Fig. 3) and is also often found on Iberian stelae, although in neither region as consistently as in Scandinavia. There, even rock carvings highlight the horned twins, but sometimes also depict what look like small warbands of horned warriors fighting bird-faced warriors (Fossum, Tanum SHFA ${ }^{101}$ 255:1) ${ }^{102}$. This latter appearance is interesting because the bird-like beaked faces or masks call to mind the horned Viksø helmets, which have a crest as well as a frontal peregrine-like beak ${ }^{103}$. From these depictions, supernatural in disposition, we may infer mythical stories of amiable or hostile connections between classes of particular warriors.

Distinct therianthropic traits are visible among the Scandinavian depictions and depositions. This could resonate with the animistic shape-shifting components of the sun-cycle NBA religion ${ }^{104}$, which differs from the Sar-

99 For example Kristiansen/Larsson 2005; Vandkilde 2013; 2014. 100 Gonzalez 2012, fig. 2b; Lilliu 1966.

101 Ling/Bertilsson 1994. https://www.shfa.se/

102 See Goldhahn 2019.

103 Goldhahn 2019; Vandkilde 2013.

104 Ahlqvist/Vandkilde 2018.
95 Pavón Soldevilla/Duque Espino 2010, fig. 4; Ledesma 2007.

96 Depalmas 2005; Salis 2014.

97 Vandkilde 2013.

98 Johannsen 2010.

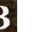



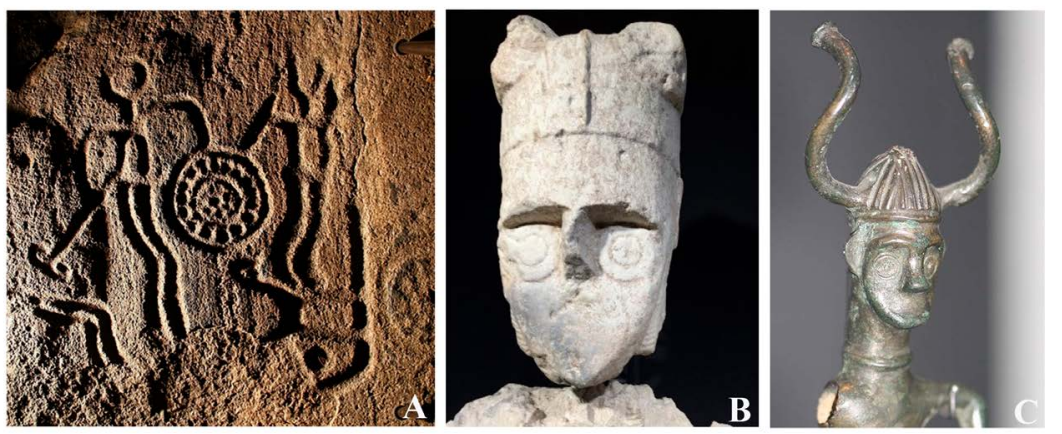

Fig. 7: A. No. 5 Hede Kville (Tanum): two horned creatures, one bigger than the other (SHFA; Ling/Bertilsson 1994, picture Ellen Meijer 2013 under a CC BY-SA 4.0 license). B. Monte Prama giant with encircled eyes and crested horned helmet, horns destroyed in antiquity (photo: H. Vandkilde, Museo Archeologico Nazionale di Cagliari). C. Grevensvænge horned creature with similar recessed and encircled eyes, though in statuette format (photo: H. Nørgaard). Not to scale.

dinian and Iberian cases. As a result, the horned warrior twins of the North can be found in disguises that deviate radically from their anthropomorphic appearance.

\section{From mini in bronze to maxi in stone: gigantisation}

Common to both Sardinian and Scandinavian horned-helmet imagery is the occurrence of bronze figurines along with translations into stone/rock. Both bronze and rock, moreover, show elements of aggrandisement. In the Tanum rock panels, the entire warrior figure sometimes appears in giant format, in all his might ${ }^{105}$. This mighty creature is often shown by oversized feet, hands, or calves, in addition to enlarged weaponry (e.g. Bro Utmark 3 at Tanum: SHFA $)^{106}$. In the Scandinavian context, the choice between metal and rock is impacted by differing geologies in the north and south of the NBA hotspot area. In Sardinia it should be taken into account that Monte Prama is archaeologically unique so far. It is nonetheless striking that, in both zones, miniature bronze representations are connected with corresponding larger presentations in stone.

Sardinia and Scandinavia, then, share an interest in bronze miniatures suitable for votive offerings. Some of these figurines are also quite similar across both regions in select stylistic features, size and - it seems - innate idea. The statuettes in bronze seem en miniature to conceptualise giant beings. This gigantisation in two modes

105 See Ling 2008, figs 8,30; 8,33; 10,20-10,22; 11,3; 12,6; 11,3. 106 Ling/Bertilsson 1994. https://www.shfa.se/ of representation, in bronze and stone, follows partly parallel tracks whereby the full-blown size in or on stone ultimately materialises at a particular point in time. The stone medium can accommodate the giants in perceived actual size - in entirety, or through chosen body parts. Enlarged or distinct hand signs, with four fingers tightly pressed together and kept separate from the accentuated thumb, is a widespread LBA-EIA symbol (of divine presence?). This symbol recurs both on the Grevensvænge figurines and on several of the Sardinian bronzetti and on S. Scandinavian rock carved slabs - in one case forming part of a temple-like construction ${ }^{107}$.

Oversized round eyes are another aggrandising trait in the bronze miniatures that recurs in both regions, with the eye rendered either as protruding or encircled. A case in point is the bronzetti produced by the RoundEye Artist, who designed a major group among the UtaAbini bronzetti in Sardinia and seems to have inspired the Monte Prama sculptures (Fig. 7) ${ }^{108}$. Similarity is particularly salient when the recessed circular eyes with a dot or inner circle depicted on the Grevensvænge twins are compared with those on the giant warriors of Monte Prama. Do these accentuated eyes signify supernatural sight? If so, they could be thought of as the eyes of divine creatures, as interestingly suggested by Joakim Goldhahn in a Nordic context ${ }^{109}$. Miniature-making and simplification enable a population to understand and control both the items and what they represent ${ }^{110}$. Similarly, aggrandisement can visualise what is beyond human control - or beyond the

107 Compare here Gonzalez 2012, fig. 2g-l. See also Kaul 1987; Dam Hansen 2019.

108 Gonzalez 2012, 95; Rendeli 2014, 188.

109 Goldhahn 2019, $129 \mathrm{ff}$.

110 Bailey 2005. 
A

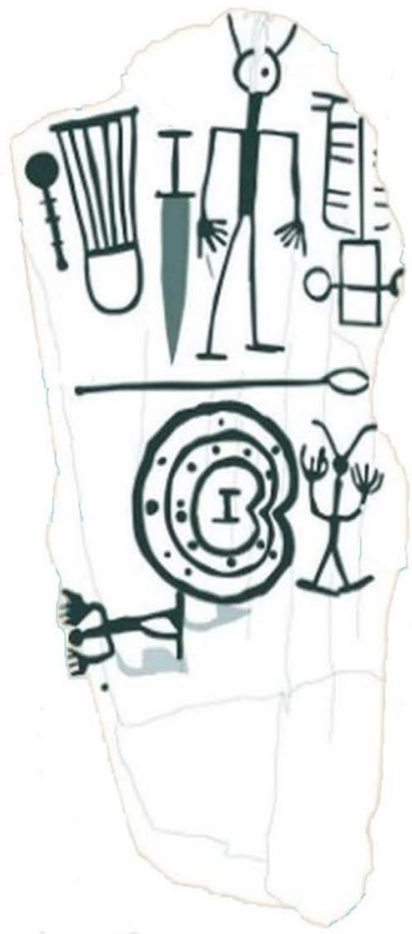

B

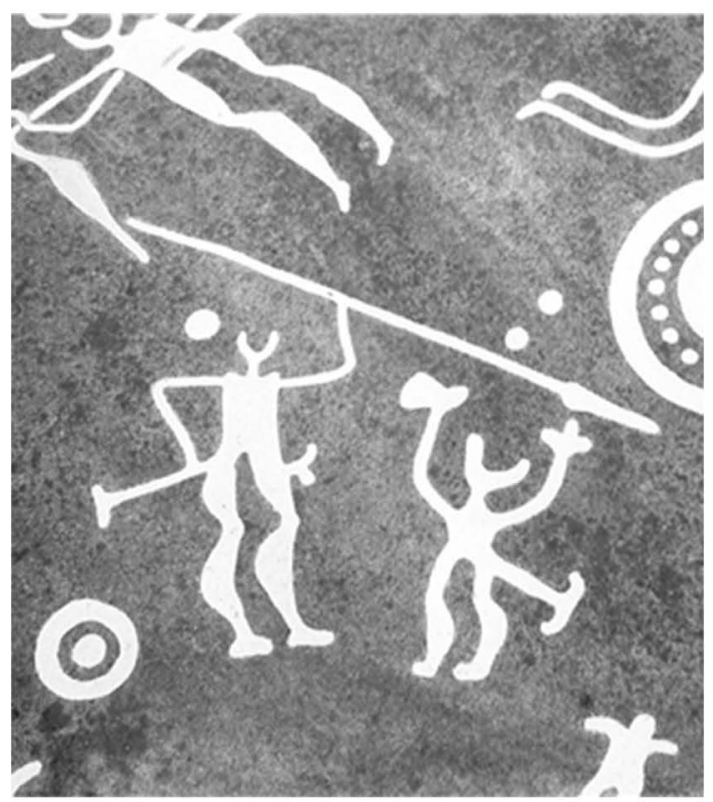

Fig. 8: Aggrandised spears and horned or unhorned creatures of various sizes. A. Jeres de los Caballeros, Badajoz (Ledesma 2007). B. Kville Hede 124, Tanum (SHFA; Ling/Bertilsson 1994, picture Åke Fredsjö 1973 under a CC BY-SA 4.0 license). Not to scale.

control of ordinary human beings. Overall, the likeness between Sardinian and Scandinavian imaging is striking.

In Iberia, the horned-helmet figure is depicted only on stelae, most of which are $130-150 \mathrm{~cm}$ tall, which means that they depict human-like figures at less than normal size ${ }^{111}$. Oversized body parts reappear nonetheless. The shape of the Iberian horns varies in a manner also found on the Tanum rock carvings. Big hands with spread fingers and large feet are also similar, and the horned-helmet figure is shown significantly larger than other human-like beings, including his twin. Thus, while the aggrandising tendencies are not systematically present in Iberia or represented by the accentuated calves often seen in Scandinavia, weapons do occur in aggrandised form, notably as spears of exaggerated length (Fig. 8).

In partial conclusion, the above comparison reveals similar traits in appearance, associations, scenes represented, and medium of representation. This is consistent with an indication that directional movements underlie the observed resemblance. While general similarities are revealed, likeness also resides in small details. Interestingly, the imagery embeds ambiguity, in that humanness and otherworldliness are depicted intertwined. Taken together, the observed congruence is too great to be gener- ated purely from local processes or randomly from multidirectional culture flows in a phase of globalisation ${ }^{112}$. The latter scenario would likely show as a geographically scattered dispersal, rather than a detached triple distribution with a western cline (cf. Fig. 1). Distinct local traits nevertheless exist in each zone, entrenched in local tradition.

\section{Comparing the sacred places of hor- ned-helmet warriors and associates}

We have identified horned-helmet imagery belonging within an array of archetypes that was probably well known to a wide public. The appearance of these images is anthropomorphic, rendered divine. Below we will show that horned-helmet imagery in all three zones is tied to sanctified places exhibiting mortuary and commemorative characteristics. As expected, local trends materialise strongly in these ritualised contexts, but Scandinavia and Sardinia in particular share a structural similarity that is interesting in light of the material likenesses revealed in the above. 


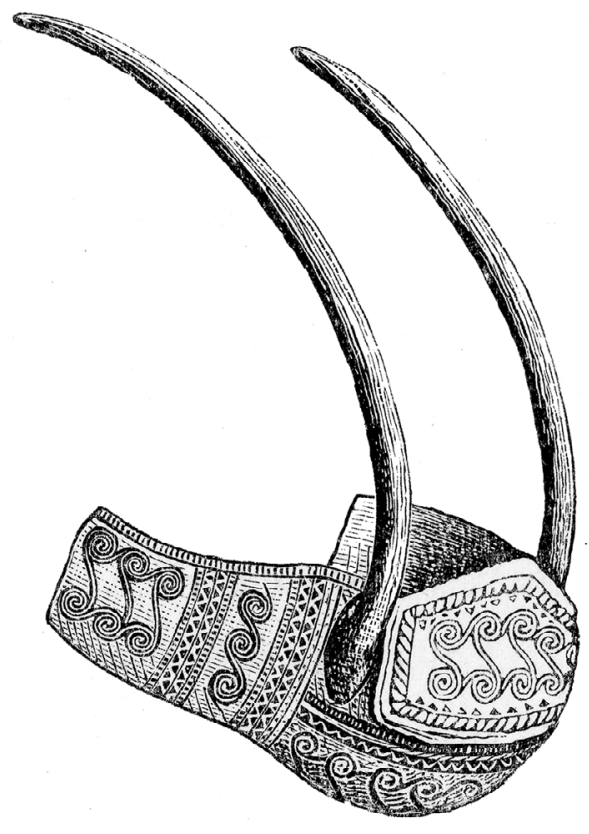

Fig. 9: The horned headdress of bronze with gold foil from a bog at Hagendrup, west Sealand, NBA II c. 1400 BC. Width 12-16 cm (after Worsaae 1882).

\section{Scandinavia}

The Vestrup Mark razor, depicting the characteristic ensemble led by the horned-helmet warrior twins, stems from a burial (cf. Fig. 3) ${ }^{113}$. This establishes a connection between the mortuary domain and the wetland depositions that, notably, include the Viksø helmets and the Grevensvænge archetypal setup of male and female figurines. In recent years, a number of special dry places have emerged dating to c. 1000/900-750 BC. Fogdarp exemplifies this innovation in place: the two horned male and two female heads on yokes were deposited with lurs and horse gear in elevated dry terrain near water ${ }^{114}$.

On the one hand, these places were used ritually, possibly relating to venerations of the sun, setting in motion the figurines of horned twins, their entourage, and/or affiliated gear, normally sized or oversized. Before deposition, these items may have been presented in ceremonial processions, perhaps as a way to connect with and venerate godlike beings or imagined ancestors from a distant past $^{115}$. On the other hand, mortuary or commemorative activities were probably interwoven with the procession. Such sites may deserve the label 'sanctuary', 'sacred land-

113 Ahlqvist 2020b.

114 Larsson 2017; Lindblad 2019.

115 Kaul 1998, 20-30; cf. Whitley 1995, 13-18. scape', or 'ceremonial gathering site'116. The Tanum rock panels may be understood in a similar light ${ }^{117}$.

These sacred sites attracted extraordinary depositions of gold and bronze items, as well as other ritual activities involving few or several people. Generally, the rich wetland depositions of NBA V should be understood as integrated parts of particular sacred landscapes, notably comprising ceremonial activities reflected in multiple fire pits $^{118}$. The Mariesminde hoard (Funen) exemplifies such a linkage between wet deposition and fire pit rows nearby. The metaphorical twins are conceptually present as golden bowls with handles shaped like the horned sun-horse, all deposited inside a bronze cauldron adorned with the sunbird-ship motif ${ }^{119}$. Such offerings and affiliated rituals likely refer to the horned-helmet warrior twins, often represented by their paired gear, as well as respectively to their broader community of male and female companions through their markers. Borgbjerg Banke (west Sealand) ${ }^{120}$, Fårdal (central Jutland), and Voldtofte (southwest Funen) are prominent sacred landscapes and special sites for cult activities, and perhaps should even be thought of as central sanctuaries appearing around the time of the horned-helmet imagery. Funerary or commemorative rites are rather distinct at Fårdal and Voldtofte ${ }^{121}$.

Five $\mathrm{km}$ from the coast at the sacred place of Voldtofte, pairs and collections of gold ornaments - perhaps linked to the horned-helmet twins and associates pars pro toto were deposited on the so-called Gold Mound presumably worshipping a claimed descendant buried there in the midst of other dynastic mounds ${ }^{122}$. Rich ritual depositions of gold and bronze objects furthermore mark the landscape surrounding the Voldtofte site. The Lusehøj mound pinpoints the uppermost social stratum that such lavish worship may have targeted. Two cremation graves of prominent males were retrieved: a bronze-adorned wagon grave, and another grave centred on an imported bronze cauldron containing cremated bones and a series of items in gold, bronze, and amber carefully wrapped in cloth $^{123}$. The tight cluster of giant mounds at Voldtofte are statements of power that link up with the nearby wealthy

116 Henriksen 1999; 2005; 2019; Mikkelsen 2011.

117 Goldhahn/Ling 2013; Ling 2008.

118 See i.e. Henriksen 2005

119 Jensen 2011; Thrane 1989.

120 Jensen 1981; Kaul 2014: at the foot of the gold-rich hill of Borgbjerg Banke there is a sacred well known for its curative powers in Medieval times.

121 Henriksen 2014; 2018; 2019; Mikkelsen 2011, 47-59.

122 Henriksen 2014; 2019; 2021.

123 Thrane 1984. 
settlement at Kirkebjerget, where swords, lurs, and ornaments were manufactured and where red-painted clay lining for walls was retrieved ${ }^{124}$. The Voldtofte rulers evidently networked with metal-trading partners both near and far in the period 1000-750 BC.

In sum, the traditional emphasis on the medium of water in ritual depositions and cults has a chthonic ambience, hinting that underground water was the imagined place of afterlife for particular creatures of the past ${ }^{125}$. Numerous outstanding objects, often in pairs, ended up in wetlands. It emerges that in NBA V an ancestral tradition was renewed by further institutionalisation, namely major cults on dry land, which seem to maintain a mortuary connotation. This may be termed a tomb or ancestor cult ${ }^{126}$. This Scandinavian development, moreover, resonates with what we can extract from the Sardinian archaeology.

\section{Sardinia}

Bronzetti in the form of anthropomorphs and zoomorphs were produced at the Sardinian sanctuaries and exhibited there as votive offerings at monumental sacred wells ( $p o z z i$ sacri). Fixed in lead, bronzetti were placed in groups along the dromos of the well that led underground. The subterranean water that sourced these wells may point to a connection with chthonic forces ${ }^{127}$. Perhaps each sacred well was thought of as a monumental temple accommodating powerful ancestors. Bronzetti offerings would then be a way to connect with and venerate these imagined ancestors of a past age $\mathrm{e}^{128}$. The models of nuraghi towers located in the middle of the Nuragic villages of the FBA-EIA would similarly become objects of commemoration and collective memory, as reminders of a mighty past $\mathrm{t}^{129}$.

It may well be that when Monte Prama was built c. $900 \mathrm{BC}$, this mortuary connotation was maintained: the warrior sculptures were erected on top of the cist graves ${ }^{130}$ as if to protect and honour the ancestral dead with a divine or semidivine presence in a traditionalising setting of Nuraghe 'towers'. The heroön character of the Monte Prama sanctuary is unique in Sardinia, and its coastal position, near the Phoenician entrepôt of Tharros at the tip

124 Thrane 1984; 2015.

125 For example Hansen 2008; Vandkilde 2014.

126 Whitley 1995.

127 Fadda 2013; 2014; Gonzalez 2012, 98; Lilliu 1988.

128 Ialongo 2013; Vella Gregory 2017; Whitley 1995, 13-18.

129 Perra 2017; see also Whitley 1995, 17.

130 Rendeli 2014, 190. of the Sinis peninsula, points not only to a further institutionalisation of ancestral cults, but also to an exogenous impact, given the easy access from the sea ${ }^{131}$.

\section{Iberia}

The warrior stelae were erected in densely settled LBA-EIA landscapes, with small stelae groups across a region. There were fortified hillforts, with conspicuous ritual depositions made in the same landscapes ${ }^{132}$. A few warrior stelae have an archaeologically attested mortuary affiliation, which can be generalised into assuming that they were initially grave markers and thereafter were commemorated in a manner difficult to specify due to sparse information about primary contexts. It is likely that at least some stelae were originally associated with burial mounds ${ }^{133}$. A stela at Cortijo de la Reina (Andalusia) was found in a ditch covering an LBA urn ${ }^{134}$, and the stela at Gomes Aires (Portugal) reportedly covered a cremation pit ${ }^{135}$.

Consistent with most interpretations, we suggest that the stelae were raised to honour special male deceased, likely an active warrior, whose body was presented on the stone slab together with a collection of his gear. The archetypal character both of each individual element and of the group is striking, as is the way the main character seems to have been praised by the use of simple codes of supreme warriorhood $^{136}$. This paper rephrases some of these codes as aggrandisement, or gigantisation. Diaz-Guardamino and colleagues ${ }^{137}$ emphasise the commemorative role and the mortuary dimension of the warrior stelae in a proximate landscape with settlements, burial mounds, droveways, fords, and water resources. In this setting of the everyday, stelae would have been important as durable and visible landmarks. Weapon deposition and warrior imagery may, as in Scandinavia, have had interchangeable meanings related to the element of water ${ }^{138}$. Unlike Sardinia and Scandinavia, however, no sanctuaries have so far been retrieved in southwest Iberia prior to the appearance of sanctuaries in Phoenician entrepôts in the eighth and seventh centuries BC in the $\operatorname{EIA}^{139}$. The long-

131 Tronchetti 2015; Tronchetti/Van Dommelen 2005.

132 Diaz-Guardamino et al. 2019b; Diaz-Guardamino et al. 2019a; Harrison 2004, 35.

133 Diaz-Guardamino et al. 2019a, 6126.

134 Ibid.

135 Harrison 2004, 310.

136 Harrison 2004, 59-65 fig. 4,5.

137 Diaz-Guardamino 2014; Diaz-Guardamino et al. 2019b, 21.

138 Gonzalez 2018, 246; Harrison 2004, 25.

139 Gonzalez 2018, 177. 
term production of stelae including aggrandising elements and special gear may suggest ongoing ancestral commemoration or even heroisation among peers, but perhaps not institutionalised cults as in Scandinavia and Sardinia.

In brief: Each of the three cases demonstrates ritualisation aligning with local practices and traditional beliefs tied to particular local landscapes. The pictured weaponry and other gear are well known from burials and hoards, both locally and in the LBA supraregion. Sun worship interfused with animistic notions seems to be a Scandinavian speciality. There are, at the same time, broad correspondences across the three ritualised contexts, which may indicate that ideas about cults, sanctuaries, and narratives moved along with material exchanges and entered local environments from the outside. An underlying political drive emerges still more persistently. Sardinia and Scandinavia in particular share exhibition and deposition of figurines and associated gear in dry as well as wet settings, and both seem to undergo a development from deeply anchored ancestral veneration to institutionalised cults of geographically broader reach. This may have progressed in tandem with local political processes. This celebrated warriorhood and ample depositions of arms points to a professionalised fighting force, conflict and violence in Final Bronze Age Europe, as several reports indicate ${ }^{140}$.

\section{Indigenous roots, innovation, and politicisation}

Our three zones adopt, invent, or reinvent the horned figure - unlike other regions at this time. In asking the question 'why', it is relevant at this point to outline the local traditions and how they evolved prior to the appearance of the horned anthropomorphs. In general terms, the horned armed figure signals both bellicosity and a preoccupation with bulls/cattle. All three of these regions thrived on animal husbandry among other economic niches, and they flagged warlike material culture and values. However, professionalised warriorhood and mixed economies of agriculture and husbandry were universal across much of LBA Europe. Local preferences and rooted tradition may nevertheless be a factor in the decision to embrace the horned-helmet imagery. Which relics of the past in the three zones might have facilitated the inclusion of the horns?

140 See for example Dolfini et al. 2018; Kristiansen/Horn 2018; Uckelmann/Mödlinger 2011.

\section{Scandinavia}

Over time, Nordic Bronze Age tradition underwent change roughly in accordance with the rhythms of those parts of Europe that were delivering metals to the North in exchange for amber ${ }^{141}$. The cyclical solar framework of the belief system in this region, with Neolithic roots, is innately resilient, and thanks to Flemming Kaul's detailed studies ${ }^{142}$ and several other contributions is well understood $^{143}$. The tripartite cosmological scheme remained fixed. The gradual implementation of cremation, c. 1400$1100 \mathrm{BC}$, does not seem to have altered belief in the sun cycle, but rather to have reinforced belief in its mortuary significance, now shared by a broader group of people than previously. In Kaul's interpretation, the sun cycle was believed to require assistance from a collegium of animal and human-like helpers, who pulled the sun nightly through the watery underworld into the sky-covered daylight, while they underwent bodily transformations along the way ${ }^{144}$. It is possible that people understood their own life/death cycle in a parallel manner throughout this long period $^{145}$, and that burials and depositions retained an ancestral and commemorative core.

The twins and other figures leading the sun's journey were likely paramount throughout the Nordic Bronze Age. They occur, implicitly for the most part, in the numerous depositions of multiple or paired objects in wetlands, pars pro toto in the sense that these godlike characters are usually not rendered present as persons but imagined or performed by human deputies (shamans/priests, community heads). For this reason the human ritual actions, social obligations, and political strategies behind the depositions should not be underestimated ${ }^{146}$. During key periods of NBA II and NBA V, this principle of imagined or performed presence during depositional acts becomes reinforced, with the sacred agents themselves emerging 'personified', that is, conceptualised in the form of bronze figurines or depicted on stone as persons. In NBA II a few person-like beings occur, notably in the hieros gamos scene on a stone slab at the Sagaholm monumental mound (Småland) ${ }^{147}$ and with the twin male figurines in the Stockhult deposition (Scania). Kristiansen and Larsson ${ }^{148}$ add horns to the

141 Nørgaard et al. 2019; 2021. 142 Kaul 1998; 2004; 2005.

143 For example Bradley 1998; Bradley/Nimura 2013.

144 Ahlqvist/Vandkilde 2018.

145 Kaul 2005.

146 Fontijn 2020, 112-129.

147 Goldhahn 1999; 2016.

148 Kristiansen/Larsson 2005, 312 fig. 143. 
twins' hats, but despite small holes in the brim, a horned reconstruction is doubtful. Horned helmets are absent in NBA II. However, both the Hagendrup headdress (Fig. 9) and the Wismar drinking horn in bronze $\mathrm{e}^{149}$ may indicate a partiality towards horned creatures, which might help to explain the later adoption of innovative horned-helmet imagery from abroad.

This was a twofold innovation dating around the transition to NBA V, c.1000-900 BC. Firstly, we see a new embodiment of the twins, now wearing horned helmets and staged within the archetypal community of anthropomorphic beings and their zoomorphic translations. These are now conceptualised as 'gigantic', whether rendered as miniatures in bronze or blown up much larger on rock. Secondly, special places of commemoration now emerge (see above), in which the sun-cycle narrative merges with large-scale mortuary and commemorative activities, often involving gear of gold and bronze of unprecedented flamboyance. Both these instances may well have been motivated by political ambition for control, as evident especially at Voldtofte.

\section{Sardinia}

The changes undergone by the Bronze Age Nuragic tradition were sensitive to the rhythm of its neighbours. Especially after $1300 \mathrm{BC}$, local metalworking developed a high level of sophistication that was dependent on both its own and imported metal sources ${ }^{150}$. As in Scandinavia, the belief system appears to have been resilient into the long term. The tradition-bound obsession with cattle horns is archaeologically conspicuous. Indeed, Sardinia is often understood specifically in terms of bulls' imagery, creatures around which the religion pivoted ${ }^{151}$, as amply expressed in the rock-cut bucrania that frequently adorn the Neolithic tombs. This tomb imagery in stone may have had multiple functions and meanings ${ }^{152}$, even if the mortuary setting points to an ancestral coupling. Cattle were also central to the Nuragic economy ${ }^{153}$. For Lilliu, Nuragic society was strictly embedded in pastoralism, as expressed in the 'king-shepherd' title he gave to the so-called Capotribu of the bronzetti at Uta-Abini ${ }^{154}$. Horned animals including bulls, stags, and rams are frequent in the Uta-

\footnotetext{
149 Kristiansen 2004.

150 For example Giumlia-Mair/Lo Schiavo 2018; Lo Schiavo 2014.

151 For example Lilliu 1958; Minoja et al. 2015.

152 Robin 2017.

153 Usai 2014, 49-50.

154 Lilliu 1966.
}

Abini group of bronzetti; these probably embody a reference to an ideal society of the past, predating the social changes that set in around $1200 \mathrm{BC}$.

At this time, the warrior bronzetti with horned metal helmets materialise on the scene. Their distinctly humanised embodiment en miniature is a completely new addition to Sardinian metalwork production, though consistent with rooted tradition. One might speculate that a proximate inspiration for this turn could perhaps have been Sardinian military troops with their horned caps. Although no such horned headgear has been preserved, the pharaonic imagery at Medinet Habu (1165 BC) holds similar headgear. No certain evidence however exists that connects those warriors with Sardinia. The south Corsican anthropomorphic menhirs may point in the direction of a regionally shared tradition of horned caps among warriors and leaders ${ }^{155}$. Such 'Sherden' warriors may have inspired the votive bronzetti, which despite their small size may have been perceived as gigantic (see above). Oxhide ingots were traded into Sardinia from Cyprus, so Cypriot horned figurines like those from Enkomi (LC III) could have been a parallel source of inspiration ${ }^{156}$.

The grandiose format of armed males at Monte Prama indicates a consolidation of institutionalised cults c. 900 $\mathrm{BC}$ and calls to mind colossal figures in the Near East and the Levant. The Monte Prama development of ancestral commemoration may also tie in with Levantine activities along the western coasts of the island ${ }^{157}$. Although emerging in negotiation with local tradition, the de facto gigantisation of entire bodies in stone seems in tune with cults of divinities, rulers, or special ancestors.

\section{Iberia}

The warrior stelae here belong to the Atlantic-West Mediterranean Bronze Age region. The local antecedents are Neolithic anthropomorphic portable idols and menhirs, as well as earlier Bronze Age stelae depicting weaponry in much the same way as the earliest series of warrior stelae ${ }^{158}$. Hence the chosen medium for the large group of Iberian later Bronze Age stelae merely continues, or rather reinvents, a rooted tradition for commemoration through the erection of stone memorials in the landscape.

155 Leandri et al. 2015.

156 See Gonzalez 2018, 43 fig. 3.

157 Usai 2014, 56-57.

158 See Ángeles Del Rincón 2017, figures 3,4; 3,9; Diaz-Guardamino 2014; Diaz-Guardamino et al. 2019a; 2019b; Koch/Palacios 2019, fig. 3,9; Martí 2017, fig. 2,11. 
The horned-helmet figure, however, is an outsider to the region. Its first appearance was likely due to LBA connections with Sardinia - perhaps fleeing military units in the course of the twelfth century BC, or brought by trading partners. The subsequent Phoenician expansion in the west could have further reinforced the significance and centralised position of the horned-helmet motif, as well as its aggrandising effects, which are consistent with the mortuary or commemorative dimension noted by several authors. Overall, the Iberian warrior stelae are embedded in a strong local tradition, while the horned-helmet warrior and his companions are intruding characters, whose appropriation locally may connect to ongoing territorialisation and control of copper and other minerals, notably in Sierra Morena, which attracted stelae on the settled plains to either side ${ }^{159}$.

\section{Summarising discussion}

The animated headgear of the horned helmet advertises the personal muscle of the wearer, and perhaps even cohesion among a group of peers. This is apparent in all three of our zones. Warfare and warriorhood, however, do not suffice as explanations. In addition, local traits pre-exist in the three zones that help to explain the adoption of horned-helmet imagery. The imagery appears self-consciously Nordic, Sardinian, and Iberian, if only because innovative exogenous traits were merged into a syncretic product suiting local culture, beliefs, and political climate. Such a reinvention of tradition may be associated with crisis or post-crisis consolidation of a new regime ${ }^{160}$. Even so, of the three zones, the Sardinian development has the clearest local foundation, and it may well be the main source of the other two zones' preoccupation with the horned-helmet warrior and novel ideas of gigantisation. The link between Sardinia and Scandinavia seems especially clear-cut, reinforced by comparable political processes, in which cults played a role.

The horned symbol of Near Eastern origin likely appeared attractive to elites in need of legitimisation. Horns attached to the head were associated with divinity, rulership, or both; the motif underlined mastery both of war and of chthonic powers ${ }^{161}$. Key meanings - including martiality, exclusivity, superpowers, authority, and divine descent - seemingly diffused into Sardinia, Iberia, and

159 Diaz-Guardamino et al. 2019b; Diaz-Guardamino et al. 2019a. 160 Hobsbawm/Ranger 1983.

161 For example Gonzalez 2012, 102.
Scandinavia. Ideas of a glorious past with horned warriors, gods, or rulers may have circulated in ways that made sense locally as a unifying collective memory, aligning with cultural tradition in each zone.

The ambiguous status of the horned-helmet figure with his entourage - not quite human, not quite divine may perhaps point towards some form of hero cult. Founding ancestors may over time have been elevated to a cult of heroes, as argued by Kristiansen and Larsson ${ }^{162}$. However, a hero cult in the Greek sense is difficult to apply, even if attached to mortal male warriors believed to dwell underground and to be able to transcend worlds owing to semidivine descent ${ }^{163}$. In Greece, hero cults per se did not gain ground until the eighth/seventh century BC. Coinciding as they did with the very beginning of Greek expansion in the western Mediterranean, this periodisation seems too late to have influenced the developments described. Whitley's ${ }^{164}$ broader 'ancestor-tomb cult' is a better fit: it is not restricted to Greece, and encompasses commemorations of the long-gone or recent dead, posthumously heroised to establish a genealogy of divine origins or territorial rights. Post-Mycenaean examples of ancestor-tomb cult notably include the Toumba heroön at Lefkandi of the tenth century BC, which concurs with the development witnessed in the three zones.

\section{Conclusion}

The above analysis has demonstrated that horns were used emblematically in Sardinia, Iberia, and Scandinavia to visualise an exclusive group of anthropomorphised warlike beings whose significance was tied to commemorative or mortuary rites, sites, and beliefs, in tandem with political trends. This is true for all three of the zones investigated. Each case portrays a localised version of a narrative intended for collective sharing about an archetypal community including human-like beings, their animal helpers, vehicles, and gear relating to war as well as peace. The imagery of very particular warriors wearing horned insignia relates on the one hand to the transfer of novel beliefs involving embodied gigantisation and on the other hand to local control of metals that were still in high demand. The three zones stand out as metal-rich, either through natural resources or through trading.

162 Kristiansen/Larsson 2005: 210, fig. 95; compare also Harrison 2004, 176-178; 143-146.

163 Albersmeier 2009; Whitley 1995, 54-57.

164 Whitley 1995, 53-61. 
Otherworldly products can be strategically designed as support for an ongoing political process aiming to legitimise and consolidate power ${ }^{165}$ and to unite rather than separate; they can be a statement of deep anchorage in situations where it was convenient to draw on the past to legitimise a changing present. It may be that our three cases can be boiled down to political domains in need of legitimisation through claimed genealogical relations to the archetypal narrative. The horned figure was appropriated very selectively, together with its narrated values of exclusivity, gigantisation, and community. The pasts of the three zones give hints of receptiveness to such a novel package in conjunction with local tradition.

These correspondences in horned-helmet imagery and the transfer between three separate zones with a distinct western cline refute one-sided explanations that privilege local processes or random culture flows. Similarities have been shown to occur on several levels, from minuscule details to the content of ideas and coinciding with politico-religious processes. The analysis has revealed a distinct core of similarity, and thus connectedness, despite long distances of transportation. Given the particular geographical spread, the most plausible link between the three zones is directional movements through a western maritime route. Association with metal-trading post-1200/1100 BC is consistent with recent research $^{166}$. The Scandinavian addendum to this network from c. 1000-900 BC coincides with the metal-led Phoenician expansion and consolidation in the west. The Phoenician capacity for sea travel and trading should be kept in mind ${ }^{167}$ although of course other actors such as the Scandinavians and Sardinians could have contributed ${ }^{168}$. A Mediterranean-Atlantic sea route emerges; the otherwise flourishing transalpine trade route seems to have been inactive in disseminating the image of the horned warrior hero. In this connection, it is significant that large quantities of Baltic amber reached Sardinia ${ }^{169}$ and were transported along the western sea route, the transalpine route, or both. Overall, our findings tally with recent reviews of the Bronze Age as a globalisation-like assemblage of multiple communities, glued together by a desire for, and dependence on, coveted metals.

165 Earle/Kristiansen 2010, 15; Earle 1997, 150-155.

166 Ben-Yosef 2019; Thompson/Skaggs 2013; Eshel et al. 2019; Wood et al. 2020; Ialongo et al. 2021.

167 Aubet 2001.

168 Compare Ling et al. 2018; Cunliffe 2001.

169 Bellintani 2010; 2016.
Acknowledgment: The research presented in this article is based on the results of two projects: We are grateful for funding granted by the Ministry of Culture Denmark FORM.2019-0032 and FORM.2020-0009. We thank the National Museum of Denmark and Flemming Kaul for permission to sample one of the Viks $ø$ helmets. We also thank Ronny Friedrich and Susanne Lindauer at the Curt-Engelhorn-Centre for Archaeometry in Mannheim, Germany, for the preparation of the radiocarbon sample, for the analysis and for the analytical assistance provided. We further wish to thank Dr. Manuela Puddu in the National Museum of Cagliari in Sardinia for the support and the permission to study the exciting Nuragic figurines. We are also grateful to Niels Algreen Møller and Marie Vang Posselt from Museum Thy, for showing us the Kallerup find while it was under conservation at Moesgaard Museum, for commenting on the manuscript and for permission to publish a photo of the twin figurine. The anonymous peer review provided valuable suggestions, which helped to improve an earlier draft of this article.

\section{References}

Ahlqvist 2020a: L. Ahlqvist, An Iconography of Monsters: A multi-scalar study of Nordic Bronze Age belt bowl and razor ornamentation (Aarhus University 2020a).

- 2020b: -, Solguden i nyt lys. Gensyn med en velkendt ragekniv (Shedding new light on the "Sun God": The Vestrup Mark razor revisited). Kuml 2020, 2020b, 85-107.

-/Vandkilde 2018: -/H. Vandkilde, Hybrid beasts of the Nordic Bronze Age. Danish Journal of Archaeology 7/2, 2018, 180-194.

Albersmeier 2009: S. Albersmeier, Heroes, Mortals and Myths in Ancient Greece (Baltimore 2009).

Althin 1952: C.-A. Althin, Hjälmarna från Viksö. Arkeologiske Forskningar och Fynd 1952, 382-396.

Ángeles Del Rincón 2017: M. Ángeles Del Rincón, El Calcolítico y la Edad del Bronce. In: I. Barandiarán/B. Martí/M. Ángeles Del Rincón/J. Luis Maya (Hrsg.), Prehistoria de la Península Ibérica (Barcelona 2017) 249-384.

Appadurai 1996: A. Appadurai, Modernity at Large. Cultural Dimensions of Globalization (Mineapolis and London 1996).

Aubet 2001: M. E. Aubet, The Phoenicians and the West. Politics, Colonies and Trade (Cambridge 2001).

Bailey 2005: D. W. Bailey, Prehistoric Figurines: Representation and Corporeality in the Neolithic (London 2005).

Barandiarán et al. 2017: I. Barandiarán/B. Martí/M. Ángeles Del Rincón/J. Luis Maya, Prehistoria de la Península Ibérica (Barcelona 2017)

Bartoloni 2017: P. Bartoloni, I Fenici dal Libano all'Atlantico. In: M. Guirguis (Hrsg.), Corpora delle Antichità della Sardegna. Sardegna Fenicia e Punica. Storia e materiali (Nuoro 2017) 31-38. 
Bedini et al. 2012: A. Bedini/C. Tronchetti/G. Ugas/R. Zucca, Giganti di Pietra. Monte Prama: l'Heroon che cambia la storia della Sardegna e del Mediterraneo (Cagliari 2012).

Bellintani 2010: P. Bellintani, Ambra: una materia prima dal nord (ma non solo). In: F. Radina/G. Recchia (Hrsg.), Ambra per Agamennone. Indigeni e Micenei tra Adriatico, Ionio ed Egeo (Mostra Bari 2010) 139-144.

- 2016: -, Il ruolo delle Alpi nella circolazione dell'ambra baltica nel Mediterraneo centrale nel corso dell'Età del Bronzo. In: P. L. Callarosi/R. Chellini/F. Martini/A. Celestino Montanaro/ L. Sarti/R. Maria Capozzi (Hrsg.), The Amber Roads. The ancient cultural and commercial communication between the peoples, Proceedings of the 1st International Conference on Ancient Roads. Studi di Archeologia Preistorica 13 (Roma 2016) 273-311.

Ben-Yosef 2019: E. Ben-Yosef, Archaeological science brightens Mediterranean dark age. PNAS 116/13, 2019, 5843-5845.

Berger et al. 2019: D. Berger/J. S. Soles/A. Giumlia-Mair/G. Brügmann/E. Galili/B. Höppner/N. Lockhoff/J. Marahrens/E. Pernicka, Isotope systematics and chemical composition of tin ingots from Mochlos (Crete), and other Late Bronze Age sites in the eastern Mediterranean Sea: An ultimate key to tin provenance?. PLoS ONE 14/6, 2019, e0218326. https://doi. org/10.1371/journal.pone.0218326

Bradley 1998: R. Bradley, The Passage of Arms. An Archaeological Analysis of Prehistoric Hoards and Votive Deposits (Oxford 1998).

- 2006: -, Danish razors and Swedish rocks: Cosmology and the Bronze Age landscape. Antiquity 80/308, 2006, 372-389.

-/Nimura 2013: -/C. Nimura, The earth, the sky and the water's edge: changing beliefs in the earlier prehistory of Northern Europe. World Archaeology 45/1, 2013, 12-26.

Brandherm 2008: D. Brandherm, The warriors' new headgear. Antiquity 82/316, 2008, 480-484.

Bronk Ramsey 1955: C. Bronk Ramsey, Radiocarbon Calibration and Analysis of Stratigraphy: The OxCal Program. Radiocarbon 37, 1955, 425-430.

Cámara Serrano/Spanedda 2014: J. A. Cámara Serrano/L. Spanedda, L'organizzazione sociale nuragica: Note e ipotesi. In: A. Moravetti/E. Alba/L. Foddai (Hrsg.), La Sardegna Nuragica: Storia e materiali (Roma 2014) 151-159.

Cleary/Gibson 2019: K. Cleary/C. Gibson, Connectivity in Atlantic Europe during the Bronze Age (2800-800 BC). In: B. Cunliffe/J. T. Koch (Hrsg.), Exploring Celtic Origins: New Ways Forward in Archaeology, Linguistics, and Genetics. Celtic Studies Publications 22 (Oxford and Philadelphia 2019) 80-116.

Cunliffe 2001: B. Cunliffe, Facing the Ocean. The Atlantic and its peoples (Oxford 2001).

Dam Hansen 2019: M. Ch. Dam Hansen, Håndtegnets udstrakte finger. En anderledes tilgang til tydningen af bronzealdermotiverne. Gefjon 4, 2019, 86-151.

Depalmas 2005: A. Depalmas, Luoghi di culto e santuari della Sardegna Nuragica. Historia Antiqua 13, 2005, 39-48.

-/Melis 2010: -/R. Melis, The Nuragic People: Their Settlements, Economic Activities and Use of the Land, Sardinia, Italy. In: I. P. Martini/W. Chesworth (Hrsg.), Landscapes and Societies (London and New York 2010) 167-186.
Diaz-Guardamino 2014: M. Diaz-Guardamino, Shaping Social Identities in Bronze Age and Early Iron Age Western Iberia: The Role of Funerary Practices, Stelae, and Statue-Menhirs. European Journal of Archaeology 17/2, 2014, 329-349.

- et al. 2019a: -/L. García-Sanjuán/D. W. Wheatley/J. A. LozanoRodríguez/M. Angel Rogerico-Candelera/M. Krueger/M. Krueger/M. Hunt Ortiz/M. Murillo-Barroso/V. Balsera Nieto, Rethinking Iberian 'warrior' stelae: a multidisciplinary investigation of Mirasiviene and its connection to Setefilla (Lora del Río, Seville, Spain). Archaeological and Anthropological Sciences 11, 2019a, 6111-6140.

- et al. 2019b: -/L. García-Sanjuán/D. Wheatley/J. A. LozanoRodríguez/M. Angel Rogerico-Candelera/M. Casado-Ariza, Late Prehistoric Stelae, Persistent Places and Connected Worlds: A Multi-disciplinary Review of the Evidence at Almargen (Lands of Antequera, Spain). Cambridge Archaeological Journal 30/1, 2019b, 69-96.

Dikaios 1962: P. Dikaios, The Bronze Statue of a Horned God from Enkomi. Archäologischer Anzeiger 1, 1962, 1-39.

Djupedal/Broholm 1953: R. Djupedal/H. Ch. Broholm, Marcus Schnabel og Bronzealderfundet fra Grevensvænge. Aarbøger for nordisk Oldkyndighed og Historie 1952, 1953, 5-59.

Dolfini et al. 2018: A. Dolfini/R. J. Crellin/Ch. Horn/M. Uckelmann, Prehistoric Warfare and Violence. Quantitative and Qualitative Approaches (London and New York 2018).

Earle/Kristiansen 2010: T. Earle/K. Kristiansen, Organizing Bronze Age Societies. The Mediterranean, Central Europe and Scandinavia compared (Cambridge 2010).

- 1997: -, How Chiefs Come to Power: The Political Economy in Prehistory (Stanford California 1997).

Eshel et al. 2019: E. Tzilla/Y. Erel/N. Yahalom-Mack/O. Tirosh/A. Gilboa, Lead isotopes in silver reveal earliest Phoenician quest for metals in the West Mediterranean. Proceedings of the National Academy of Sciences 116/13, 2019, 6007-6012.

Fadda 2013: M. A. Fadda, Nel segno dell'acqua. Santuari e bronzi votivi della Sardegna nuragica (Sassari 2013).

- 2014: -, L'architettura dedicate al culto dell'acqua. In: Alberto Moravetti/Elisabetta Alba/Lavinia Foddai (Hrsg.), La Sardegna Nuragica - storia e materiali (Sassari 2014) 79-92.

Fontijn 2020: D. Fontijn, Economies of Destruction. How the systematic destruction of valuables created value in Bronze Age Europe c. 2300-500 BC (London and New York 2020).

Fredell et al. 2010: Å. C. Fredell/K. Kristiansen/F. Criado Boado, Representations and Communications: Creating an Archaeological Matrix of Late Prehistoric Rock Art (Oxford and Philadelphia 2010).

Giumlia-Mair/Lo Schiavo 2018: A. Giumlia-Mair/F. Lo Schiavo, Bronze Age Metallurgy on Mediterranean Islands. In honour of Robert Maddin and Vassos Karageorgis. Monographie Instrumentum 56 (Drémil-Lafage 2018).

Glob 1962: P. V. Glob, Kultbåde fra Danmarks Bronzealder. Kuml 1961, 1962, 9-18.

Glob 1969: P. V. Glob, Helleristninger i Danmark. Jysk Arkæologisk Selskabs skrifter VII (Odense/Copenhagen 1969).

Goldhahn 1999: J. Goldhahn, Sagaholm: hällristningar och gravritual. Studia archaeologica Universitatis Umensis 11 (Jönköping 1999).

- 2016: -, Sagaholm - North European Bronze Age rock art and burial ritual (Oxford 2016). 
- 2019: -, Birds in the Bronze Age. A North European Perspective (Cambridge 2019).

Goldhahn/Ling 2013: J. Goldhahn/J. Ling, Bronze Age Rock Art in Northern Europe: Contexts and Interpretations. In: $\mathrm{H}$. Fokkens/A. F. Harding (Hrsg.), The Oxford Handbook of the European Bronze Age (Oxford 2013) 270-290.

Gonzalez 2012: R. A. Gonzalez, Sardinian bronze figurines in their Mediterranean setting. Praehistorische Zeitschrift 87/1, 2012, 83-109.

- 2018: -, Inter-Cultural Communications and Iconography in the Western Mediterranean during the Late Bronze Age and the Early Iron Age (Rhaden/Westfalen 2018).

Hagberg 1988: U. E. Hagberg, The Bronze Shields from Fröslunda near lake Vänern, West Sweden. In: B. Hårdh/L. Larsson/D. Olausson/R. Petré (Hrsg.), Trade and exchange in prehistory. Studies in honour of Berta Stjernquist. Acta Archaeologica Ludensia Series $8^{\circ}$, no.16 (Lund 1988) 119-126.

Hansen 1995: S. Hansen, Aspekte des Gabentauschs und Handels während der Urnenfelderzeit in Mittel-und Nordeuropa im Lichte der Fundüberlieferung. In: B. Hänsel (Hrsg.), Handel, Tausch und Verkehr im bronze-und früheisenzeitlichen Südosteuropa (München and Berlin 1995) 67-80.

- 2008: -, Bronzezeitliche Horte als Indikatoren für "andere Orte". Das Altertum 53, 2008, 291-314.

Harding 2007: A. F. Harding, Warriors and Weapons in Bronze Age Europe (Budapest 2007).

Harrison 2004: R. J. Harrison, Symbols and Warriors: Images of the European Bronze Age (Bristol 2004).

Hencken 1971: H. Hencken, The earliest European helmets: Bronze Age and Early Iron Age. American School of Prehistoric research, Peabody Museum, Harvard University Bulletin No. 88 (Cambridge, Mass. 1971).

Henriksen 1999: M. B. Henriksen, Bål i lange baner - om brugen af kogegruber i yngre bronzealder og ældre jernalder. Fynske Minder 1999, 93-128.

- 2005: -, Danske kogegruber og kogegrubefelter fra yngre bronzealder og ældre jernalder. In: L. Gustafson/T. Heibreen/J. Martens (Hrsg.), De gåtefulle kokegroper. Kokegropseminaret 31. november 2001 (Oslo 2005) 77-102.

- 2014: -, Guldhøjen. Skalk 5, 2014, 3-9.

- 2018: -, Højgravsfeltet på Voldtofte Vestermark. Nye fund og perspektiver. In: S. Boddum/N. Terkildsen (Hrsg.), Status og samfundsstruktur i yngre bronzealders kulturlandskab. Vol. 6. Seminarrapport, Viborg Museum \& Holstebro Museum (Viborg \& Holstebro 2018) 211-235.

- 2019: -, Da Voldtofte var verdens centrum. Straatag 2019, 11-16.

- 2021: - B. Henriksen, Voldtofte - et sydvestfynsk magtcenter fra bronzealderen. Rids af 180 års forskning - og vi er stadig $i$ gang! Odense Bys Museer Årbog 2021, 71-91.

Hobsbawm/Ranger 1983: E. Hobsbawm/T. Ranger, The Invention of Tradition (Cambridge 1983).

Ialongo 2013: N. Ialongo, Sanctuaries and the Emergence of the Elites in Nuragic Sardinia during the Early Iron Age (ca. 950-720 BC): The Actualization of a 'Ritual Strategy'. Journal of Mediterranean Archaeology 26/2, 2013, 187-209.

lalongo et al. 2021: N. Ialongo, R. Hermann, L. Rahmstorf, Bronze Age weight systems as a measure of market integration in Western Eurasia. Proceedings of the National Academy of Sciences July 2021, 118(27) e2105873118; DOI: 10.1073/ pnas. 2105873118
Jensen 1981: J. Jensen, Et rigdomscenter fra yngre bronzealder på Sjælland. Aarbøger for Nordisk Oldkyndighed og Historie 1981, 48-96.

Jensen 2011: L. Ewald Jensen, Kogegrubefelter og votivfund - det fynske eksempel. In: S. Boddum/M. Mikkelsen/N. Terkildsen (Hrsg.), Depotfund i yngre bronzealders lokale kulturlandskab. Seminarrapport fra seminariet Depotfund i yngre bronzealders lokale kulturlandskab i Viborg 4. marts 2010 (Viborg 2011) 27-36.

Johannsen 2010: J. Winther Johannsen, The Wheeled vehicles of the Bronze Age on Scandinavian rock-carvings. Acta Archaeologica 81, 2010, 150-250.

Jung 2009: R. Jung, "Sie vernichteten sie, als ob sie niemals existiert hätten” - Was blieb von den Zerstörungen der Seevölker? In: H. Meller (Hrsg.), Schlachtfeldarchäologie/Battlefield Archaeology. 1. Mitteldeutscher Archäologentag vom 09. bis 11. Oktober 2008 in Halle (Saale)Tagungen Landesmuseum für Vorgeschichte Halle 2 (Halle [Saale] 2009) 31-48.

- et al. 2011: -/M. Mehofer/E. Pernicka, Metal Exchange in Italy from the Middle to the Final Bronze Age $\left({ }^{14}\right.$ th- ${ }^{11}$ th Century BCE). In: Ph. P. Betancourt/S. C. Ferrence (Hrsg.), Metallurgy: Understanding How, Learning Why. Studies in Honor of James D. Muhly. Prehistory Monographs 29 (Philadelphia 2011) 231-248.

Kaul 1987: F. Kaul, Sandagergård - a Late Bronze Age Cultic Building with Rock Engravings and Menhirs from Northern Zealand, Denmark. Acta Archaeologica 56, 1985 (1987), 31-54.

- 1998: -Kaul, Ships on Bronzes. A Study in Bronze Age Religion and Iconography. Publications from the National Museum Studies in Archaeology and History (Copenhagen 1998).

- 2004: -, Bronzealderens religion. Studier af den nordiske bronzealders ikonografi. Nordiske Fortidsminder Serie B22 (Copenhagen 2004).

- 2005: -, Bronze Age tripartite cosmologies. Prähistorische Zeitschrift 80, 2005, 135-148.

- 2010: -, En kultøkse fra Nordsjælland. Kultøkser og hornede hjelme i yngre bronzealder. In: M. Andersen/P. O. Nielsen (Hrsg.), Danefæ. Skatte fra den danske muld (til Hendes Majestæt Dronning Margrethe 2.) (Copenhagen 2010) 80-84.

- 2014: -, Bronze Age gold from Denmark. In: H. Meller/R. Risch/E. Pernicka (Hrsg.), Metalle der Macht - Frühes Gold und Silber/ Metals of power - Early gold and silver. 6. Mitteldeutscher Archäologentag vom 17. bis 19. Oktober 2013 in Halle (Saale). Tagungen des Landesmuseum für Vorgeschichte Halle 11 (Halle [Saale] 2014) 885-902.

Koch 2018: J. T. Koch, Rock art and Celto-Germanic vocabulary. Shared iconography and words as reflections of Bronze Age contact. Adoranten 2018, 1-16.

-/Palacios 2019: -/F. Palacios, A case of identity theft? Archaeogenetics, Beaker People, and Celtic origins. In: B. Cunliffe/J. T. Koch (Hrsg.), Exploring Celtic Origins. New Ways Forward in Archaeology, Linguistics, and Genetics. Celtic Studies Publications (Oxford 2019) 38-79.

Kossack 1954: G. Kossack, Studien zum Symbolgut der Urnenfelderund Hallstattzeit Mitteleuropas. Römisch-Germanische Forschungen 20 (Berlin 1954).

Kristiansen 1998: K. Kristiansen, Europe Before History. New Studies in Archaeology (Cambridge 1998).

- 2004: -, Kivikgraven, Wismarhornet, Simrisristningerne og den nordiske bronzealderns begyndelse. In: G. Milstreu/H. Prøhl 
(Hrsg.), Prehistoric Pictures as Archaeological Source. GOTARC series C, Arkeologiska Skrifter 50 (Tanumshede 2004) 69-84.

- 2014: -, The dialectics of gender: Ritualizing gender relations in Late Bronze Age southern Scandinavia. In: H. Alexandersson/ A. Andreeff/A. Bünz (Hrsg.), Med hjärta och hjärna: en vänbok till professor Elisabeth Arwill-Nordbladh. GOTARC series A, Gothenburg archaeological studies 5 (Göteborg 2014) 339-354.

-/Horn 2018: -/Ch. Horn, Warfare in Bronze Age Society (Cambridge 2018).

-/Larsson 2005: -/Th. B. Larsson, The Rise of Bronze Age Society (New York 2005).

-/Suchowska-Ducke 2015: K. Kristiansen/P. Suchowska-Ducke, Connected Histories: the Dynamics of Bronze Age Interaction and Trade 1500-1100 BC. Proceedings of the Prehistoric Society 81, 2015, 361-392.

Kromer et al. 2013: B. Kromer/S. Lindauer/H.-A. Synal/L. Wacker, MAMS - A new AMS facility at the Curt-Engelhorn-Centre for Achaeometry, Mannheim, Germany. Nuclear Instruments and Methods in Physics Research Section B 294, 2013, 11-13.

Lai et al. 2014: L. Lai/O. Fonzo/E. Pacciani/T. O’Connell, Isotopi stabili e radioattivi: primi dati su dieta e cronologia assoluta delle sepolture di Mont'e Prama. In: A. Usai/M. Minoja (Hrsg.), Le sculture di Mont'e Prama - Contesto, scavi e materiali (Roma 2014) 207-218.

Larsson 1990: L. Larsson, A man's head on a wagon-yoke. In: Olaf Olsen (Hrsg.), Oldtidens ansigt - Faces of the past. Til Hendes Majestæt Dronning Margrethe II 16. april 1990 (Copenhagen and Aarhus 1990) 64-65.

- 1974: -, The Fogdarp Find. Meddelanden från Lunds Universitet Historiska Museum 1973-74, 1974, 169-238.

- 2011: -, Wetland Settlements in Prehistoric Sweden. In: E. Pranckénaité (Hrsg.), Wetland settlements of the Baltic: a prehistoric perspective (Vilnius 2011) 7-30.

- 2017: -, One face still lost but another gained. In: B. V. Eriksen/A. Abegg-Wigg/R. Bleile/U. Ickerodt (Hrsg.), Interaction without borders: Exemplary archaeological research at the beginning of the $21^{\text {st }}$ century: Festschrift für Claus von Carnap-Bornheim zum 60. Geburtstag (Schleswig 2017) 111-118.

Leandri et al. 2015: F. Leandri/K. Peche-Quilichini/J. Cesari, Iconographie comparée et contextualisée des statuesmenhirs corses et des bronzetti anthropomorphes sardes. In: G. Rodriguez/H. Marchesi (Hrsg.), Statues-menhirs et pierres levées du Néolithique à aujourd'hui. Actes du 3e colloque international sur la statuaire mégalithique, Saint-Pons-de-Thomières, du 12 au 16 septembre 2012 (SaintPons-de-Thomières 2015) 299-311.

Ledesma 2007: C. G. Ledesma, Estelas decoradas del S.0. de la peninsula Ibérica (http://www.estelasdecoradas.es/paginas/ galeria_estelas_extremadura.htm 2007)

Lilliu 1958: G. Lilliu, Religione della Sardegna pre-nuragíca. Bullettino di Paletnologia Italiana 66, 1958, 7-96.

- 1966: -, Sculture della Sardegna Nuragica (Cagliari 1966).

- 1988: -, La civiltà dei sardi. Dal paleolitico all'età dei nuraghi (Gennaio 1988).

Lindblad 2019: T. Lindblad, Fogdarpsfyndet: En landskapsanalys av ett depåfynd från den yngre bronsåldern (Uppsala University 2019).

Ling 2008: J. Ling, Elevated rock art. Towards a maritime understanding of Bronze Age rock art in northern Bohuslän. Sweden. Gothenburg Archaeological Thesis 49 (Göteborg 2008).
-/Bertilsson 1994: -/C. Bertilsson, Swedish Rock Art Research Archive's (SHFA) image database https://www.shfa.se

- et al. 2012: -/E. Hjärthner-Holdar/L. Grandin/K. Billström/P.-O. Persson, Moving metals or indigenous mining? Provenancing Scandinavian Bronze Age artefacts by lead isotopes and trace elements. Journal of Archaeological Science 40, 2012, 1-14.

- et al. 2014: -/Z. Stos-Gale/L. Grandin/K. Billström/E. Hjärthner-Holdar/P.-O. Persson, Moving metals II: provenancing Scandinavian Bronze Age artefacts by lead isotope and elemental analyses. Journal of Archaeological Science 41, 2014, 106-132

-/Koch 2018: -/J. T. Koch, A sea beyond Europe to the North and the West. In: J. Dodd/E. Meijer (Hrsg.), Giving the Past a Future. Essays in Archaeology and Rock Art Studies in Honour of Dr Phil h.c. Gerhard Milstreu (Oxford 2018) 96-111.

- et al. 2018: -/T. K. Earle/K. Kristiansen, Maritime Mode of Production. Raiding and Trading in Seafaring Chiefdoms. Current Anthropology 59, 2018, 488-524.

- et al. 2019: -/E. Hjärthner-Holdar/L. Grandin/Z. Stos-Gale/K. Kristiansen/A. L. Melheim/G. Artioli/I. Angelini/R. Krause/C. Canovaro, Moving metals IV: Swords, metal sources and trade networks in Bronze Age Europe. Journal of Archaeological Science: Reports 26, 2019, 1-34.

Lo Schiavo 2014: F. Lo Schiavo, La produzione metallurgica. In: A. Moravetti/E. Alba/L. Foddai (Hrsg.), La Sardegna Nuragica: Storia e materiali (Sassari 2014) 93-120.

- et al. 2009: -/M. Perra/A. Usai/F. Campus/V. Leonelli/P. Bernardini, Sardegna: le ragioni dei cambiamenti nella civiltà nuragica. Scienze dell'Antichità, Storia Archeologia, Antropologia 15/2009, 2009, 265-289.

Lundström 2009: F. Lundström, Benskenklädda akajer, gladiatorer och stora vader - sydskandinaviska bronsåldersavbildningar i en stridskontext. In: T. Svensson/Ch. Hedenstierna-Jonson/E. Lindkvist/S. Vasilyeva/M. Gerhards (Hrsg.), Spaden och pennan: ny humanistisk forskning $i$ andan av Erik B. Lundberg och Bengt G. Söderberg (Stockholm 2009) 189-204.

Manunza 2008: M. R. Manunza, Funtana Coberta: Tempio nuragico a Ballao nel Gerrei (Cagliari 2008).

Martí 2017: B. Martí, El Neolítico. In: I. Barandiarán/B. Martí/M. Á. Del Rincón/J. L. Maya (Hrsg.), Prehistoria de la Península Ibérica (Barcelona 2017) 155-248.

Matta et al. 2020: V. Matta/H. W. Nørgaard/D. Stott/H. Vandkilde/M. Kähler Holst, The Mountain Sanctuary of Matzanni in Sardinia: Project Motivations and Preliminary Research Results. Open Archaeology 2020/6, 2020, 206-213. https://doi.org/10.1515/ opar-2020-0114

Melheim et al. 2018: A. L. Melheim/L. Grandin/P.-O. Persson/K. Billström/Z. Stos-Gale/J. Ling/A. Williams/l.

Angelini/C. Canovaro/E. Hjärthner-Holdar/K. Kristiansen, Moving metals III: Possible origins for copper in Bronze Age Denmark based on lead isotopes and geochemistry. Journal of Archaeological Science 96, 2018, 85-105.

Mikkelsen 2011: M. Mikkelsen, Fårdalfundet i yngre bronzealders kulturlandskab - fra periferi til centrum. In: S. Boddum/M. Mikkelsen/N. Terkildsen (Hrsg.), Depotfund i yngre bronzealders lokale kulturlandskab. Seminarrapport fra seminariet Depotfund i yngre bronzealders lokale kulturlandskab Viborg 4. marts 2010 (Viborg 2011) 37-61. 
Minoja et al. 2015: M. Minoja/G. Salis/L. Usai, L'isola delle torri. Giovanni Lilliu e la Sardegna Nuragica. Catalogo della mostra (Sassari 2015).

-/Usai 2014: -/A. Usai, Le sculture di Mont'e Prama - Contesto, scavi e materiali (Roma 2014).

Molloy 2010: B. Molloy, Swords and swordsmanship in the Aegean Bronze Age. American Journal of Archaeology 114/3, 2010, 403-428.

- 2018: -, Conflict at Europe's Crossroads: Analysing the Social Life of Metal Weaponry in the Bronze Age Balkans. In: A. Dolfini/R. J. Crellin/Ch. Horn/M. Uckelmann (Hrsg.), Prehistoric Warfare and Violence. Quantitative Methods in the Humanities and Social Sciences (Cham 2018) 199-224.

Murillo-Redondo et al. 2005: J. F. Murillo-Redondo/J. A. MorenaLópez/D. Ruiz-Lara, Nuevas estelas de guerrero procedentes de las provincias de C'ordoba y de Ciudad Real. ROMULA 4, 2005, 7-46.

Mödlinger 2015: M. Mödlinger, Bronzezeitliche Schutzwaffen. In: H. Meller/M. Schefzik (Hrsg.), Krieg - eine archäologische Spurensuche. Begleitband zur Sonderausstellung im Landesmuseum für Vorgeschichte Halle (Saale) 6. November 2015 bis 22. Mai 2016 (Halle (Saale) 2015) 293-296.

- 2017: -, Protecting the Body in War and Combat. Metal Body Armour in Bronze Age Europe. Oriental and European Archaeology (Vienna 2017).

Norling-Christensen 1943: H. Norling-Christensen, Bronzealderhjælmene fra Viksø. Nationalmuseets Arbejdsmark 1943, 1943, 5-18.

- 1946a: -, Bronzealderhjælmene fra Viksø. Nationalmuseets gule bøger (Copenhagen 1946).

- 1946b: -, The Viksø Helmets. Acta Archaeologica 17, 1946, 99-115.

Nørgaard et al. 2019: H. W. Nørgaard/E. Pernicka/H. Vandkilde, On the trail of Scandinavia's early metallurgy: provenance, transfer and mixing. PLoS ONE 14/7: e0219574, 2019 1-32. https://doi. org/10.1371/journal.pone.0227504

- et al. 2021: -/E. Pernicka/H. Vandkilde, Shifting networks and mixing metals: Changing metal trade routes to Scandinavia correlate with Neolithic and Bronze Age transformations. PLoS ONE 16/6: e0252376. https://doi.org/10.1371/journal. pone. 0252376

Olsen et al. 2011: J. Olsen/K. Margrethe Hornstrup/J. Heinemeier/P. Bennike/H. Thrane, Chronology of the Danish Bronze Age Based on C-14 Dating of Cremated Bone Remains. Radiocarbon Vol 53(2), 2011, 261-275.

Pavón Soldevilla/Duque Espino 2010: I. Pavón Soldevilla/D. M. Duque Espino, La Nueva Estela de Guerrero de las Bodeguillas (Esparragosa de Lares, Badajoz) y el Paisaje Cultural del Final de la Edad del Bronce en la Serena. SPAL 19, 2010, 111-128.

Pérez 2001: S. C. Pérez, Estelas de guerrero y estelas diademadas. La precolonización y formación del mundo tartésico (Barcelona 2001).

-/López-Ruiz 2008: -/C. López-Ruiz, Response to D. Brandherm’s article “The Warrior's New Headgear”. Antiquity 82, 2008, 485-497.

Perra 2017: M. Perra, I modelli di Nuraghe come memoria collettiva di una civiltà. In: A. Moravetti/P. Melis/L. Foddai/E. Alba (Hrsg.), La Sardegna nuragica. Storia e monumenti, Corpora delle Antichità della Sardegna (Sassari 2017) 67-84.

Reimer et al. 2013: P.J. Reimer/E. Bard/A. Bayliss/J. Warren Beck/P. G. Blackwell/Chr. Bronk Ramsey/C. E. Buck/H.
Cheng/R. L. Edwards/M. Friedrich/P. M. Grootes/Th. P. Guilderson/H. Haflidason/I. Hajdas/Ch. Hatté/T. J. Heaton/D. L. Hoffmann/A. G. Hogg/K. A. Hughen/K. F. Kaiser/B. Kromer/S. W. Manning/M. Niu/R. W. Reimer/D. A. Richards/E. M. Scott/J. R. Southon/R. A. Staff/Ch. S. M. Turney/J. Van Der Plicht, IntCal13 and Marine13 Radiocarbon Age Calibration Curves 0-50,000 Years cal BP. Radiocarbon 55, 2013, 1869-1887.

Rendeli 2014: M. Rendeli, Mont'e Prama. In: A. Moravetti/E. Alba/L. Foddai (Hrsg.), La Sardegna Nuragica - storia e materiali (Sassari 2014) 179-192.

Robin 2017: G. Robin, What are Bucrania Doing in Tombs? Art and Agency in Neolithic Sardinia and Traditional South-East Asia. European Journal of Archaeology 20/4, 2017, 603-635.

Salis 2014: G. Salis, Navicelle nuragiche. In: A. Moravetti/E. Alba/L. Foddai (Hrsg.), La Sardegna Nuragica - storia e materiali (Sassari 2014) 429-452.

Sansoni/Gavaldo 2015: U. Sansoni/S. Gavaldo, Alpine and Scandinavian rock art in the Bronze Age: a common cultural matrix in a web of continental influences. In: P. Skoglund/J. Ling/U. Bertilsson (Hrsg.), Picturing the Bronze Age (Oxford and Philadelphia 2015) 129-142.

Schaeffer 1966: C. F.-A. Schaeffer, Götter der Nord- und Inselvölker in Zypern. Archiv für Orientforschung 21, 1966, 1966, 59-69.

Scott et al. 2021: A. Scott/R. C. Power/V. Altmann-Wendling/M. Artzy/M. A. S. Martin/St. Eisenmann/R. Hagan/D. C. SalazarGarcia/Y. Salmon/D. Yegorov/I. Milevski/I. Finkelstein/Ph. W. Stockhammer/Ch. Warinner, Exotic foods reveal contact between South Asia and the Near East during the second millennium BCE. PNAS 118/2, e2014956117, 2021.

Sprockhoff 1954: E. Sprockhoff, Nordische Bronzezeit und frühes Griechentum. Jahrbuch des Römisch-Germanischen Zentralmuseum Mainz 1954, 28-110.

Stockhammer 2004: Ph. W. Stockhammer, Zur Chronologie, Verbreitung und Interpretation urnenfelderzeitlicher Vollgriffsschwerter. Tübinger Texte 5 (Rhaden/Westfalen 2004).

Stuiver/Polach 1977: M. Stuiver/H. A. Polach, Discussion: Reporting of 14 C Data. Radiocarbon 19/3, 1977, 355-363.

Sørensen 2012: T. Flohr Sørensen, Original Copies; seriality, similarity, and the simulacrum in the Early Bronze Age. Danish Journal of Archaeology 1/1, 2012, 45-61.

Thompson/Skaggs 2013: Ch. Thompson/S. Skaggs, King Solomon's silver? Southern Phoenician hacksilber hoards and the location of Tarshish. Internet Archaeology 35, 2013.

Thrane 1975: H. Thrane, Europæiske forbindelser. Bidrag til studiet af fremmede forbindelser i Danmarks yngre broncealder (periode IV-V). Nationalmuseets skrifter, Arkæologiskhistoriske række XVI (København 1975).

- 1984: -, Lusehøj ved Voldtofte - en sydfynsk storhøj fra yngre bronzealder. Fynske Studier XIII (Odense 1984).

- 1989: -, De 11 guldskåle fra Mariesminde - vidnesbyrd om en broncealderhelligdom? Fynske Minder 1989, 13-30.

- 1999: -, Grevensvænge. Reallexikon der germanischen Altertumskunde 13, 23, 1999.

- 2015: -, Kirkebjergbopladsens støbeaktiviteter. In: S. Boddum/M. Mikkelsen/N. Terkildsen (Hrsg.), Bronzestøbning i yngre bronzealders kulturlandskab. Seminarrapport fra seminaret Bronzestøbning i yngre bronzealders lokale kulturlandskab i Viborg, 6. marts 2014 (Viborg 2015) 121-130. 
Treherne 1995: P. Treherne, The Warrior's Beauty: The masculine Body and self-identity in Bronze Age Europe. Journal of European Archaeology 3/1, 1995, 105-144.

Tronchetti 2014: C. Tronchetti, Gli scavi del 1977 E 1979. In: A. Usai/M. Minoja (Hrsg.), Le sculture di Mont'e Prama Contesto, scavi e materiali (Roma 2014) 155-174.

- 2015: -, Cultural Interactions in Iron Age Sardinia. In: B. A. Knapp/P. Van Dommelen (Hrsg.), The Cambridge Prehistory of the Bronze and Iron Age Mediterranean (Cambridge 2015) 266-284.

-/Van Dommelen 2005: -/P. Van Dommelen, Entangled Objects and hybrid Practices: Colonial Contacts and Elite Connections at Monte Prama, Sardinia. Journal of Mediterranean Archaeology 18/2, 2005, 183-208.

Uckelmann 2012: M. Uckelmann, Die Schilde der Bronzezeit in Nord-, West-und Zentraleuropa. Prähistorische Bronzefunde III,4 (Stuttgart 2012).

-/Mödlinger 2011: -/M. Mödlinger (Hrsg.), Bronze Age Warfare: Manufacture and Use of Weaponry. BAR International Series 2255 (Oxford 2011).

Ugas 2014: G. Ugas, La Sardegna nuragica. Aspetti generali. In: A. Moravetti/E. Alba/L. Foddai (Hrsg.), La Sardegna Nuragica: Storia e materiali (Sassari 2014) 11-34.

Usai 2014: A. Usai, Alle origini del fenomeno di Mont'e Prama. La civiltà nuragica nel Sinis. In: M. Minoja/A. Usai (Hrsg.), Le sculture di Mont'e Prama. Contesto, scavi e materiali (Roma 2014) 29-72.

- 2015: -, Mont'e Prama 2015. Nota preliminare. Quaderni della Soprintendenza Archeologia della Sardegna 26, 2015, 75-111.

Vandkilde 2013: H. Vandkilde, Bronze Age Voyaging and Cosmologies in the Making: the Helmets from Viksø Revisited. In: S. Bergerbrant/S. Sabatini (Hrsg.), Counterpoint: Essays in Archaeology and Heritage Studies in Honour of Professor Kristian Kristiansen (Oxford 2013) 165-177.
- 2014: -, Breakthrough of the Nordic Bronze Age: Transcultural Warriorhood and a Carpathian Crossroad in the Sixteenth Century BC. European Journal of Archaeology 14/4, 2014, 602-633.

- 2016: -, Bronzization: The Bronze Age as Pre-Modern Globalization. Praehistorische Zeitschrift 91/1, 2016, 103-123.

- 2017: -, The Metal Hoard from Pile in Scania, Sweden. Place, things, time, metals, and worlds around 2000 BCE. The Swedish History Museum, Studies 29 (Stockholm 2017).

- 2021: -, Trading and weighing metals in Bronze Age Western Eurasia, Proceedings of the National Academy of Sciences July 2021, 118/30: e2110552118; DOI: 10.1073/pnas.2110552118

- et al. 1996: -/U. Rahbek/K. Lund Rasmussen, Radicarbon Dating and the Chronology of Bronze Age Southern Scandinavia. In: K. Randsborg (Hrsg.), Absolute Chronology. Archaeological Europe 2500-500 BC (København 1996) 183-198.

Varberg et al. 2016: J. Varberg/B. Gratuze/F. Kaul/A. Haslund Hansen/M. Rotea/M. Wittenberger, Mesopotamian glass from Late Bronze Age Egypt, Romania, Germany and Denmark. Journal of Archaeological Science 74, 2016, 184-194.

Vella Gregory 2017: I. Vella Gregory, Mediterranean. Sardinia. In: T. Insoll (Hrsg.), The Oxford Handbook of Prehistoric Figurines (Oxford 2017) 799-822.

Whitley 1995: J. Whitley, Tomb cult and hero cult. The uses of the past in archaic Greece. In: N. Spencer (Hrsg.), Time, Tradition and Society in Greek Archaeology (London 1995) 119-126.

Wood et al. 2020: J. R. Wood/C. Bell/I. Montero-Ruiz, The origin of Tel Dor hacksilver and the westward expansion of the Phoenicians in the Early Iron Age: The Cypriot connection. Journal of Eastern Mediterranean Archaeology \& Heritage Studies 8/1, 2020, 1-21.

Worsaae 1882: J. J. A. Worsaae, The Industrial Arts of Denmark. From the Earliest Times to the Danish Conquest of England (London 1882). 